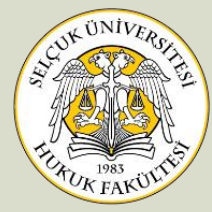

\title{
TÜRK İŞ HUKUKUNDA UZAKTAN ÇALIŞMA KAPSAMINDA IŞVERENIN İŞ SAĞLIĞI VE GÜVENLİĞINI SAĞLAMA BORCU
}

\author{
Arş. Gör. Dr. Kübra DEMIR*
}

Öz

Uzaktan çalışma; esasında eskiden beri uygulanan bir çalışma türü olmasına karşın son yıllarda dünyada ve ülkemizde yaygınlık kazanmış ve pandemi süreci ile birlikte daha sık gündeme gelmeye başlamıştır. Uzaktan çalışmada çalışanlar ile işveren arasındaki ilişki iş organizasyonu çerçevesinde bağımlılık ilişkisine dayansa dahi bu kapsamda gerçekleştirilen çalışmalar işyeri dışında gerçekleştirildiğinden işverenin işçi üzerindeki denetim ve yönetim yetkisi diğer çalışma türlerine göre daha zayıftır. İşverenin iş ilişkisi içerisindeki yükümlülüklerinden birisi iş sağlı̆̆ 1 ve güvenliğini sağlama borcudur. İşverenin uzaktan çalışma kapsamında çalıştırdığı işçilerin iş sağlığı ve güvenliğini sağlamakla yükümlü olması konusunda bir tereddüt bulunmamaktadır. Ancak işçilerin iş görme edimini işyeri dışında yerine getirmelerinden dolayı iş sağlı̆̆ı ve güvenliğine ilişkin bazı kuralların uygulanmasında güçlük çıkabilmektedir. Bunun yanı sıra uzaktan çalışma esnasında meydana gelen iş kazası ve meslek hastalıklarından işverenin sorumlu tutulması için birtakım şartlar aranacaktır. Bu çalışma kapsamında uzaktan çalışma sırasında işverenin, iş sağlığı ve güvenliğini sağlama borcu ve iş kazası ve meslek hastalıklarından hangi hallerde sorumlu tutulabileceği ele alınmaya çalışılacaktır.

* $\quad$ Arş. Gör. Dr, Sivas Cumhuriyet Üniversitesi Hukuk Fakültesi, İş ve Sosyal Güvenlik Hukuku Anabilim Dalı, Sivas, Türkiye | Research Assist., Sivas Cumhuriyet University, Faculty of Law, Department of Labour and Social Security Law, Sivas, Turkey.

凹koz@cumhuriyet.edu.tr• ORCID 0000-0002-2073-5085

Atıf Şekli | Cite As: DEMİR Kübra, "Türk İş Hukukunda Uzaktan Çalışma Kapsaminda İşverenin İş Sağlığı ve Güvenliğini Sağlama Borcu", SÜHFD., C. 29, S. 3, 2021, s. 2501-2543.

Intihal | Plagiarism: Bu makale intihal programında taranmış ve en az iki hakem incelemesinden geçmiştir. I This article has been scanned via a plagiarism software and reviewed by at least two referees. 


\title{
Anahtar Kelimeler
}

Uzaktan Çalışma • Tele Çalışma • Evden Çalışma • İş Kazası ve Meslek Hastalığı $\bullet$ İş Sağlığı ve Güvenliği

\section{OBLIGATION TO PROVIDE OCCUPATIONAL HEALTH AND SAFETY OF THE EMPLOYER WITHIN THE SCOPE OF REMOTE WORKING IN TURKISH LABOR LAW}

\begin{abstract}
Remotework is an ancient type of study, it has become widespread globally and in our country in recent years. This type of work has started to come to the fore more frequently with the pandemic. The relationship between remote workers and the employer is based on dependency within the framework of the work organization. However, since the works carried out in this context are carried out outside the workplace, the employer's control and management authority over the worker is weaker than other types of work. One of the employer's obligations in the business relationship is the obligation to provide occupational health and safety within the scope of the obligation of protecting and observing the worker.There is no hesitation about the employer's obligation to ensure workers' occupational health and safety within the scope of remote work. However, because the workers perform their job outside the workplace, it may be difficult to apply some occupational health and safety rules. In addition, will seek certain coinditions to hold the employer responsible for work accidents and occupational diseases during remote work. Within the scope of this study, it will be tried to deal with the employer's obligation to ensure occupational health and safety during remote work, and in which cases the employer can be held responsible for work accidents and occupational diseases, and will briefly mention the legal sanctions of the employer's violation of this obligation.
\end{abstract}

\section{Key Words}

Remote Work • Tele Work • Home Work • Occupational Accidents and Professional Diseases $\bullet$ Occupational Health and Safety

\section{GíRIŞ}

İş hukuku klasik iş ilişkileri üzerine şekillenmiştir. Genel olarak belirsiz süreli iş sözleşmesine dayanan ve oldukça sıkı bir hiyerarşik ilişki içinde işverenin emir ve talimatlarına bağlı olarak coğrafi sınırları belirli olan işyerlerinde, tam gün çalışma esasına dayanan iş ilişkileri özellikle son 30 yıl içerisinde meydana gelen değişim ve gelişimler üze- 
rine oldukça köklü dönüşüm geçirmiştir. Bu dönüşüm beraberinde atipik iş ilişkilerini getirmiştir. ${ }^{1}$

İş hukukunun bugüne kadarki gelişim süreci ağırlıklı olarak işçinin daha fazla korunması ihtiyacı yönünde olmuştur. Ancak 1970'li yıllardan sonra toplumsal gelişmelere bağlı olarak çalışma hayatı da farklı görünüm kazanmaya başlamıştır. Klasik iş ilişkileri, esnek iş ilişkileri olarak tanımlanan yeni çalışma türlerinin baskısı altında kalmaya başlamıştır. İş hukukundaki esneklik arayışının nedenleri olarak; işletmelerin rekabet gücünü koruma ve artırma gereği, teknolojik gelişmeler ve işsizliğin azaltılarak, istihdamın teşvik edilmesi ve son dönemde dünya ülkelerini derinden etkileyen salgın hastalıklar gösterilebilir. ${ }^{2}$ Esasında çalışma hayatının esnekleştirilmesi ile anlatılmak istenen şeyin iş güvencesi, feshe karşı koruma, fesih halinde ödenmesi gereken tazminatlar gibi işçiyi koruyucu hükümlerin esnekleştirilmesi olduğu öğretide ifade edilen görüşler arasındadır. Öyle ki bu görüşe göre iş hukukunun iş yaratma ve istihdama olumlu yönde etkisi ancak iş hukukunun ekonomiyi düzenleyebildiği ve hatta iş hukukunun ekonomiye hakimiyet kurduğu ütopik ortamlarda anlamlıdır. Dolayısıyla iş hukukunun "esnekleşme" ile beraber istihdamı artırabileceği hususu mevcut durumda gerçekliğe uymamaktadır. ${ }^{3}$ Üstelik çalışma hayatında esneklik sağlayacağı pek çok yararın yanında kayıt dışı istihdamın artmasına da neden olmakta ve işçi açısından istikrarsız bir çalışma ortamına neden olmaktadir. ${ }^{4}$

Çalışma hayatındaki esneklik anlayışının ${ }^{5}$ en önemli getirilerinden birisi olan uzaktan çalışma kavramı esasen yeni bir çalışma biçimi değil-

1 DULAY YANGIN Dilek, “6715 Sayılı Yasanın Uzaktan Çalışmaya İlişkin Hükümleri ve Değerlendirilmesi" Sicil, Sayı: 36, 2016, s. 149.

2 EYRENCİ Öner, "Çalışma Hayatında Güncel Gelişmeler ve Çağdaş Bir İş Yasası.” Sosyal Siyaset Konferansları Dergisi, Sayı: 46, 2002, s. 158, 159., İNCİROĞLU Lütfi, Çalışma Hayatında Esnek Çalışma Uygulamaları, Güncellenmiş 2. Baskı, Legal Yayınevi, 2020, s. 193.

3 YILDIZ Gaye Burcu, "İş Hukukunun Etkinliği ve Amacı Üzerine Yeniden Düşünmek" Çalışma ve Toplum, 2018/2 (57), s. 737.

4 ŞEN, Elif, “Evde Hizmet Sözleşmesi” Uyuşmazlık Mahkemesi Dergisi, Sayı: 10, 2017, s. 477.

5 İş hukukunda esnekleştirme hususu kuralsızlaştırma olarak anlaşılmamalıdır. Esnekleşmenin kuralsızlaştırma şeklinde yorumlanması insan onuruna yaraşır iş kavramı ile çelişecektir. Böyle bir yaklaşım ise iş hukukunun çıkış ve var oluş amacı ile bağdaşmayacağı gibi işçiyi koruma esasına da aykırıdır. Esnekliğin kuralsızlaştırma 
dir. Özellikle uzaktan çalışma kavramı içerisinde yer alan evde çalışma, tarihin ilk dönemlerinden bugüne kadar varlığını sürdürmüştür. Günümüzde uzaktan çalışma; geleneksel yöntemlere dayanılarak yapılan üretim biçimleri dışında tele çalışma gibi modern yöntemlerle de yerine getirilen iş ilişkilerini kapsamaktadır. Klasik istihdam modeline alternatif olarak görülebilecek olan uzaktan çalışma modeli genellikle kadınlar, engelli bireyler, öğrenciler gibi çalışma hayatında dezavantajlı sayılabilecek gruplar tarafından tercih edilmektedir. ${ }^{6}$ İşçilerin uzaktan çalışma modelini seçme sebepleri arasında özel hayatları ile iş hayatları arasındaki dengeyi kurmak temel sebep olarak gösterilebilir. İşverenler ise uzaktan çalışma modelini seçerken ekonomik maliyetin temel alındığ1 bir yaklaşım sergilemektedir. Üretim maliyetlerinin düşürülme çabası, gittikçe daha sık yaşanmaya başlanan ekonomik krizler ve uluslararası rekabette yaşanan artışlar bu çalışma modelinin işverenlerce benimsenmesinde esaslı nedenler olmaktadır. İş ilişkisi içerisinde tarafların bu çalışma biçimini tercih etmelerinin yanı sıra artık devletler de işsizlik sorununun aşılması için esnek çalışma biçimlerini benimsemekte ve işçi ve işverenlerin devletler tarafından bu çalışma biçimine özendirildiği görülmektedir. ${ }^{7}$ Var olan istihdam modelleri tek tip bir modele indirgenemez. İşverenlerin işgücü maliyetini düşürme çabaları ise adeta iş kanunlarını dolanmaya kapı açacaktır. Her iki duruma karşı çözüm bulunması için iş hukukunun kapsamının genişlemesi ve değişen koşullarla beraber iş hukukunun alanının daraltılarak esnek düzenlemelere daha fazla kapı açılması gerektiği ifade edilmiştir. ${ }^{8}$ Ancak madalyonun öteki yüzünde iş hayatı ve özel hayatın birbiri ile iç içe geçmesi, iş-yaşam dengesinde bozulmaların meydana gelmesi ve bu durumun doğuracağ1 psiko-sosyal riskler işverenin bu duruma yönelik gözetim borcu kapsamında alacağı önlemler, yapılacak iş ile ilgili özellikle tele çalışmalarda veri güvenliğinin temini ve dijital platformlarda gerçekleştirilen çalışma-

şeklinde düşünülmesi çalışma hayatını adeta Sanayi Devrimindeki çalışma koşullarına geri götürecektir. YILDIZ, s. 737.

6 GÜNAY Arkın, Türk Hukukunda ve Karşılaştırmalı Hukukta Evden Çalışma, Legal Yayınevi, 2018, s. 3.

7 ÇELIKK Nuri/CANIKLIOĞLU Nurşen/CANBOLAT Talat, İş Hukuku, Yenilenmiş 33. Bas1, Beta, 2020, s. 226.

8 YILDIZ, s. 736. 
ların doğurduğu güvencesiz çalışma modelleri çalışma hayatında önemli sorunlar doğurabilecek niteliktedir. ${ }^{9}$

Atipik bir istihdam modeli olan uzaktan çalışmada tarafların iş ilişkisinden doğan borçları diğer iş ilişkilerinden farklılık göstermeyecektir. İş̧̧inin asıl edimi iş görme, işverenin asıl edimi ise görülen iş karşılığında ücret ödemektir. Ancak iş sözleşmesinden doğan birtakım borçlar bu sözleşme tipinde özel olarak değerlendirilmeyi gerekli kılabilmektedir. Her ne kadar bu sözleşme tipinde de işçi edimini işverenin iş organizasyonu içerisinde yerine getirmekteyse de diğer çalışma türlerinden farklı olarak bu edim işvereninin hâkimiyet sahası dışında yerine getirilmektedir. ${ }^{10} \mathrm{Bu}$ durum uzaktan çalışma kapsamında iş sağlı̆̆ 1 ve güvenliğinin özel olarak değerlendirilmesi sonucunu doğurmaktadır. Çalışma kapsamında ilk olarak uzaktan çalışma ve uzaktan çalışmanın alt başlıkları olan evde çalışma ve tele çalışma tanıtılmaya çalışılacaktır. Ayrıca Türk Borçlar Kanununda düzenlenen evde hizmet sözleşmesine de kısaca değinilecek ve işverenin iş sağlı̆̆1 ve güvenliğini sağlama borcunun uzaktan çalışma kapsamındaki görünümü tanıtılmaya çalış1lacaktir.

\section{UZAKTAN ÇALIŞMA}

Genel bir kavram olan uzaktan çalışma (remote work), tele çalışma, evde çalışma, gezici satış temsilcileri gibi birçok çalışan kesimini içermektedir. Bu çalışma türünün diğer çalışma türlerine göre ayırt edici unsuru işyeri ile ilgili yer ve zaman sınırlarının nispi hale gelmesidir. Bu sayede işçiler, iş görme edimlerini işyerlerinden farklı yerlerde yerine getirseler de tek bir işyeri organizasyonu vardır. Öğretide bu durum "hizmetlerin âdemi merkezileştirilmesi" şeklinde ifade edilmiştir. ${ }^{11}$

Uzaktan çalışma 4857 sayılı İş Kanununda (İK) ${ }^{12}$ "işçinin, işveren tarafından oluşturulan iş organizasyonu kapsamında iş görme edimini evinde ya da teknolojik iletişim araçları ile işyeri dışında yerine getirmesi esasına dayalı ve yazılı olarak kurulan iş ilişkisi" olarak tanımlanmış-

DULAY YANGIN Dilek, “Endüstri 4.0., Dijitalleşme ve İş Hukukunun Geleceği Dijital Platformların Ortaya Çıkardığı Hukukî İlişkiler Çerçevesinde Değerlendirilmesi. (Dijitalleşme)" İstanbul Hukuk Mecmuası, 78 (3), 2020, s. 1218. 1209-1237.

10 ÇELIK/CANIKLIOĞLUU/CANBOLAT, s. 237.

11 EYRENCİ Öner, “Tele Çalışma ve İş Hukuku” İHD., Cilt:1, Sayı: 2, 1991, s. 199., GÜNAY, s. 80.

12 RG. $10.06 .2003,25134$. 
tır. (md. 14/4) ${ }^{13}$ Uzaktan çalışma yöntemleri konusunda bir terim birliği bulunmamaktadır. Söz konusu durum Türk Hukukuna özgü bir durum değildir. Aynı biçimde Alman Hukukunda da uzaktan çalışma konusunda terim birliği bulunmamakta; kanunda evde çalışma ve tele çalışma terimleri birlikte kullanılmakla beraber özellikle tele çalışma hususunda kapsam ve çalışma yeri açısından esaslı biçimde alt ayrım yapmanın mümkün olduğu ifade edilmiştir. ${ }^{14}$

Uzaktan çalışmada işçinin iş görme edimini işverenin emir ve talimatları doğrultusunda yerine getireceği konusunda bir tereddüt bulunmamaktadır. Ancak işçi çalışma türünün özelliğinden dolayı çalışma süresini büyük ölçüde ya da tamamen belirleyebilme serbestîsine sahiptir. ${ }^{15}$

4857 sayılı Kanunda uzaktan çalışma sözleşmelerinde nelerin yer alması gerektiği belirtilmiştir. Uzaktan çalışmaya dayalı iş sözleşmelerinde işin tanımı, yapılma şekli, süresi ve yeri, ücret ve ücretin ödenmesine ilişkin hususlar, işveren tarafından sağlanan ekipman ve bunların korunmasına yönelik yükümlülükler ve sözleşmeye ilişkin özel ve genel çalışma şartlarına ilişkin hükümler bulunur. ${ }^{16}$ (md. 14/5)

Uzaktan çalışmayı karakterize eden unsurlar mesafe, işverenin iş organizasyonu içerisinde iş görme ve tele çalışmalarda bilgi iletişim teknolojileridir. Mesafe unsuru ve işverenin iş organizasyonu içerisinde iş görme unsuru tüm uzaktan çalışmalar için ortak unsurdur.

\section{A. Mesafe Unsuru}

İş Kanununda yapılan tanımdan hareketle uzaktan çalışmanın gerek evde çalışmayı gerekse teknolojik iletişim araçları ile işyeri dışında yapılan çalışmaları yani tele çalışmayı kapsayan bir üst kavram olduğu söylenebilir. ${ }^{17}$ Madde düzenlemesinde evde çalışma ve tele çalışma me-

13 Türk Hukukunda uzaktan çalışmaya ilişkin yasal düzenleme “İş Kanunu ve Türkiye İş Kurumu Kanununda Değişiklik Yapılmasına Dair Kanun” kapsamında 2016 yılında İş Hukuku mevzuatına dâhil olmuştur.

14 GÜMRÜKÇÜOĞLU BOZKURT Yeliz, “Covid-19 Pandemi Döneminde HomeOffice Uygulamasına İlişkin Türk ve Alman Hukuku'nda Mukayeseli Bir Değerlendirme", Koronavirüs Döneminde Güncel Hukuki Meseleler Sempozyumu. İstanbul: İbn Haldun Üniversitesi Yayınları, 29-30 Mayıs 2020, s. 154, 155.

15 GÜNAY, s. 81.

16 Uzaktan çalışmanın usul ve esaslarının belirlenmesine ilişkin yönetmelik 10 Mart 2021 tarihinde yayımlanan 31419 sayılı Resmi Gazete ile yürürlüğe girmiştir.

17 SÜZEK Sarper, İş Hukuku, 20. Baskı, Beta Yayınevi, 2020, s. 267., İNCİROĞLU, s. 193. 
safe unsuru göz önünde tutularak uzaktan çalışma üst başlığ 1 kapsamında ele alınmıştır. Öğretide Kanunda yapılan tanımlamada vurgulanan mesafe unsuru yerinde bulunmuştur. Çünkü bu çalışma türünü karakterize eden unsur işin sınırları belirli ve ana işyeri olarak nitelendirilen coğrafi alan dışında ifa edilmesidir. Mesafe unsuru ise işçinin edimini yerine getirmesi esnasında, işverenin gözetleme ve denetleme imkânından yoksun bulunması olarak ifade edilebilir. ${ }^{18}$

\section{B. İşverenin İş Organizasyonu İçerisinde İş Görme Unsuru}

Uzaktan çalışmada önemli olan işin tamamen ya da kısmen işyeri dışında görülmesidir. Bu nedenle uzaktan çalışma kavramında ölçüt olarak işyeri kullanılmaktadır. ${ }^{19}$ Uzaktan çalışmayı karakterize eden unsurlardan birisi mesafe unsuru iken bir diğeri işverenin iş organizasyonu içerisinde iş görmedir. Bu unsur işçi ve işveren arasındaki olması gereken "bağımlılık" ilişkisini tanımlar. ${ }^{20}$

14. maddede yapılan tanımlamada bir iş ilişkisinin uzaktan çalışma olarak nitelendirilebilmesi için işçinin iş görme edimini işveren tarafından oluşturulan iş organizasyonu içerisinde yerine getirmesi gerektiği ifade edilmiştir. Daha önce belirtildiği üzere taraflar arasındaki bağımlılık ilişkisinin belirlenmesinde temel kıstas işverenin iş organizasyonu içerisinde iş görmedir. ${ }^{21}$

İş sözleşmelerini diğer sözleşmelerden ayırma hususunda kullanılan "bağımlılık" ölçütü üzerinde uzlaşılmış bir kavram değildir. Bağımlılık unsuru belirlenirken yasal düzenlemelerden ziyade bilimsel çalışmalardan ve mahkeme kararlarından yararlanılmaktadır. Yargıtay tarafından verilen kararlarda da iş hukukunun dinamik yapısının hukuki dayanaklarının tanımlanmasını güçleştirdiğini ve ekonomik ve teknolo-

\footnotetext{
18 DULAY YANGIN, s. 150.

19 İNCİROĞLU, s. 194.

20 İş sözleşmesini diğer iş görme sözleşmelerinden ayıran en önemli unsurlardan birisi "bağımlılık"tır. İş Kanununda yer alan iş sözleşmesinin tanımında da bir tarafın bağımlı olarak iş görmeyi üstlendiği sözleşme denilerek bu unsur özellikle vurgulanmıştır. (md. 8)., ancak İş Kanununda bağımlılık unsurundan açıkça bahsedilmeseydi bile iş sözleşmesi ve işçinin varlığ için bağımlılık unsurunun gerekli olduğu kuşkusuzdur. BAŞTERZİ Süleyman, “Avukatla Bağıtlanan Sözleşmenin Hukukî Niteliği, İş Sözleşmesinin Vekâlet ve Diğer İş Görme Sözleşmelerinden Ayrılması", Sicil, Sayı: 17, 2010, s. 178.

21 DULAY, s. 151.
} 
jik değişim ve gelişimlerin iş ve sosyal güvenlik hukukunu hızla dönüştürdüğü ifade edilmiştir. ${ }^{22}$

$\mathrm{Bu}$ çalışma kapsamında incelenecek olan uzaktan çalışmalarda işverenin iş sağlığı ve güvenliğini sağlama borcu kapsamında bağımlılık meselesi özel önem arz etmektedir. Çünkü bu çalışma türünde bağıml1lık diğer çalışma türlerine nazaran daha zayıf durumdadır. Bu durum özellikle işverenin denetim ve gözetim yetkisinin yoğun olduğu koruma ve gözetme borcunda kendini göstermektedir.

Gelişen teknolojiler iş hukukundaki bağımlılık unsurunun zayıflamasına neden olmaktadır. Özellikle belirtildiği üzere bilgisayar teknolojilerinin kullanımı işverenin fiili denetim ve gözetimi altında çalışmanın öneminin yitirilmesine yol açmaktadır. Dolayısıyla iş sözleşmesinde bağımlılık unsuru hakkındaki görüşlerin de değişmesi normaldir ve bağımlılık konusunda tek bir görüşe dayanılarak yapılan çözümlemeler de yeterli olmayacaktır. ${ }^{23}$ Öğretide bağımlılık unsurunda meydana gelen bu değişme tüm dünyanın yaşadığ 1 Covid-19 salgınına yapılan atıf ile nükteli bir şekilde bağımlılık unsurunun "mutasyona" uğraması şeklinde yorumlanmiştır. ${ }^{24}$

İşçi ve işveren arasındaki bağımlılık ilişkisini belirleyen ve klasikleşmiş olan üç temel boyut bulunmaktadır. Bunlar ekonomik bağımlılık, teknik bağımlılık ve kişisel-hukukî bağımlılıktır. Bu bağımlılık türleri zaman içerisinde iş sözleşmelerini diğer sözleşmelerden ayırmak amacıyla ortaya çıkarılmıştır. Ekonomik bağımlılık, iş ilişkilerinin ekonomik boyutunu temel alarak yapılan yorumlarda öne sürülmüştür. İşçilerin iş ilişkisinde zayıf konumda olması ve almış oldukları ücretlerle geçinen kimseler olması sebebiyle işveren ile aralarındaki ilişkinin ekonomik bağımlılık olduğu savunulmuştur. ${ }^{25}$

22 Yarg. HGK. 02.02.2005, E: 2004/10-737, K: 2005/26, ERDENK Erdem. İş Hukukunda İsimsiz (Karma ve Kendine Özgü) Sözleşmeler. Legal Yayınevı, 2008, s. 89.

23 ERDENK, s. 90.

24 TUNCAY, s. 39.

25 İşçi ile işveren arasındaki teknik bağımlılık ise işyerinde bulunan araç-gereç ve hammadde gibi maddi unsurlar ve maddi olmayan diğer unsurların kullanılarak iş görülmesine bağlı olan bağımlılık olarak yorumlanmıştır. Teknik bağımlılık her iş ilişkisinde mevcut değildir. Çünkü yapılması maddi olan veya olmayan donanıma bağlı olmayan işler de mevcuttur ve böyle bir durumda teknik bağımlılığın kabul edilmesi halinde işçi ve işveren arasında bağımlılıktan söz edilemeyecektir. BAŞTERZİ, s. 179, 180. 
Öğretide iş̧i ile işveren arasındaki bağımlılık ilişkisinin hukukî bağımlılık mı yoksa ekonomik bağımlılık mı olduğu sorusuna ağırlıklı olarak hukukî bağımlılık olduğu yönünde kanaat getirilmiştir. Bu açıdan işçinin işverene ekonomik yönden bağımlılı̆̆ iş sözleşmelerini diğer iş görme sözleşmelerinden ayırt etmeyecektir. İşs sözleşmesinin getirisi olan bağımlılık kişisel bir bağımlılıktır ve bu bağımlılık türü iş̧̧i ile işveren arasında diğer sözleşmelerde olmayan bağımlılık ilişkisi kurar. ${ }^{26}$

Yargitay tarafından verilen kararda iş sözleşmesini belirleyen ölçütün hukukî-kişisel bağımllılı olduğu ifade edilmiştir. Buna göre işçinin hukukî bağımlılığ iş̧̧inin işin yürütümüne ve işyerindeki talimatlara uyma yükümlülüğünü içerir. Bağımlılık unsuru içerisinde işverenin talimatlarına göre hareket etmeyi ve iş süreci ve sonuçlarının işveren tarafından denetlenmesini barındırır. İşin işverene ait işyerinde görülmesi ise bağımlılık unsuru için aranan esaslı şartlardan birisi değildir. $\mathrm{Bu}$ durum işçi ile işveren arasındaki kişisel bağımlılığın tespitinde kullanılacak yardımcı olgulardan sadece biridir. Bağımlılık ilişkisinin belirlenmesinde tek başına bir ölçüt teşkil etmeyeceği gibi işçinin işverenin emir ve talimatlarına bağlı kalarak ancak işin görülmesi esnasında serbest hareket etmesi bağımlılık ilişkisini ortadan kaldırmayacaktır. ${ }^{27}$ Yargitay tarafından verilen bir başka kararda da çalışan kişinin işin yürütümünü kendisi organize etse bile üzerinde iş sahibinin belirli ölçüde kontrol ve denetimi söz konusuysa, iş sahibine bilgi ve hesap verme yükümlülüğü varsa, doğrudan iş sahibinin otoritesi altında olmasa da bağımlı çalışan olduğu kabul edilir. ${ }^{28}$

Bağımllılı unsuru her ne kadar iş sözleşmesinin temel unsuru olsa da her iş ilişkisinde bu unsur ayn yoğunluğa sahip değildir. Özellikle işin niteliği ve yerine getiriliş tarzı bağımlılığın yoğunluğunun belirlenmesinde önemli kriterlerdendir. Ancak her halde yapılacak işe bağlı olarak şekillenecek bağımlılık unsuru ortadan kalkmayacaktır. Aksi durumda tarafların arasındaki hukukî ilişki artık iş sözleşmesi olarak nite-

\footnotetext{
26 SÜMER Haluk Hadi, "İş Sözleşmesinin Bağımlılık Unsuru, (Bağımlılık Unsuru).” Sicil, Sayı 19, 2010, s. 69.

27 Yarg. 9. HD. 2.3.2015, 2903/8612., SÜMER Halûk Hadî, İş Hukuku Uygulamaları, 7. Baskı, Seçkin Yayınc1lı, 2019, s. 8.

28 Yarg. 9. HD. 23.02.2010, E: 2008/10530, K: 2010/4617, Çalışma ve Toplum, Sayı: 27, s. $259,260$.
} 
lendirilemeyecektir. Bu durumda iş görme edimini yerine getiren kişi de işçi sayılmayacaktır. ${ }^{29}$

İşverene ait iş organizasyonu içerisinde onun yararına iş görme kavramı ile işçinin işverene olan bağımlılığı belirlenirken somut olayın özellikleri göz önünde bulundurulmalı ve sınırlar buna göre belirlenmelidir. Örneğin bir tekstil atölyesi için fason üretimde bulunan başka bir işletme sahibi, işverene ait üretim organizasyonunda onun yararına iş görmesine rağmen aralarında bağımlılık ilişkisi bulunmamaktadır. ${ }^{30}$ İşyerinin organizasyon olma özelliği ile beraber işyeri salt bir "yer" olmaktan uzaklaşmaktadır. İşyerinden bahsedebilmek için mutlaka bir yerde örgütlenmesi gerekmez bu nedenle işletmelerin merkezi sayılan yerler dışında çalışanlar da işyeri personeli sayılırlar. İşverene ait iş organizasyonu kavramı yalın bir ifade ile işyerinin sınırlarını belirleyen ölçüttür. Bu halde aynı teknik amaca yönelmiş olan işçilerin kendi evlerinden ya da belirledikleri başka bir yerden iş görmeleri ile beraber bu yerler "işyerine bağlı olan yerler" olarak değerlendirilmelidir. ${ }^{31}$

Eski Borçlar Kanunu ${ }^{32}$ döneminde evde yapılan işlere ilişkin istisnai bir düzenleme getirilmiş ve evde parça başına çalışan işçinin, işverenin doğrudan doğruya denetim ve gözetimi altında olmaması sebebiyle bu tür çalışma ilişkilerine istisna sözleşmelerine dair hükümlerin uygulanacağı düzenlenmişti. (BK md.322) Öncelikle belirtilmelidir ki iş sözleşmeleri veya Türk Borçlar Kanununda (TBK) ${ }^{33}$ kullanılan biçimi ile hizmet sözleşmelerinde ücretin parça başına kararlaştırılmış olması taraflar arasındaki sözleşmeyi hizmet sözleşmeyi olmaktan çıkarmaz. Her ne kadar işçi ile işveren arasındaki bağımlılık zayıflasa dahi yukarıda yapılan açıklamalar neticesinde işçi edimini işverene bağlı organizasyon içerisinde yerine getirmektedir. Bağımlılık ile anlaşılması gereken husus işverenin işçisine her an emir ve talimat verme imkânına sahip olabilmesi olarak değerlendirilebilirse de işverenden aldığı parçalar ile iş görmek için emir alan ancak bu işi işyerinde değil de işyeri dışında bir yerde yapmak için işverenle anlaşan işçinin çalıştığ 1 yer arasında herhangi bir farklılık bulunmamaktadır. Böylelikle bağımlılığın az veya çok olması

\footnotetext{
29 SÜMER (Bağımlılık Unsuru), s. 69.

30 SÜMER (Bağımlılık Unsuru), s. 70.

31 YAVUZ Cevdet, Borçlar Hukuku Özel Hükümler, Güncellenmiş ve Yenilenmiş 17. Baskı, Beta Yayınevi, 2021, s. 539.

32 RG. 29.04.1926, 359.

33 RG.4.2.2011, 27836.
} 
taraflar arasındaki ilişkiyi iş sözleşmesi olmaktan çıkaramayacaktır. ${ }^{34}$ Eski Borçlar Kanununda yer alan bu hükme isabetli olarak yeni Türk Borçlar Kanununda yer verilmemiştir.

Uzaktan çalışmanın türleri ve TBK'da yer alan evde hizmet sözleşmesi hakkında kısaca bilgi verildikten sonra işverenlerin bu çalışma türlerinde iş sağllğ 1 ve güvenliğini sağlama yükümlülüklerini ne şekilde yerine getirebilecekleri açıklanmaya çalışılacaktır.

\section{Evde Çalışma}

Evde çalışma, tele çalışmaya nazaran oldukça eski tarihlerden beri uygulanmaktaysa da özellikle son yıllarda tüm dünyada ve ülkemizde yaygınlık kazanmaya başlamıştır. Özellikle konfeksiyon ve tekstil işlerinde eve iş verme sistemi daha çok kullanılmakta ancak son zamanlarda da reklamcılık, çeviri, mimarlık gibi çalışma alanları da evden çalışma ile yerine getirilmektedir. ${ }^{35}$

Evde çalışmaya ilişkin uluslararası düzenlemelerden birisi olan ILO'nun (International Labour Organization) 177 sayılı “Evde Çalışma Sözleşmesi” evde çalışmayı "...bağlı olduğu işverene ait işyeri veya sair bir tesis dışında evinde, ücret karşılığında işverenin belirlediği bir malı ya da hizmeti üreten kişinin çalışması" olarak tanımlamıştır. Avrupa Birliği ( $\mathrm{AB})$ düzenlemelerinde ise evde çalışma ve uzaktan çalışmaya ilişkin düzenleme Avrupa Çerçeve Anlaşması ile gerçekleştirilmiştir. Bu Anlaşma ile uzaktan ve evden çalışan kimselerin çalışma koşullarına ilişkin genel çerçevenin belirlenmesi ve çalışanların asgari haklarının güvence altına alınması amaçlanmıştır. ${ }^{36} 177$ sayılı ILO Sözleşmesi ve 184 sayılı ILO Tavsiye Kararı evde tele çalışmayı da kapsamaktadır. Bu nedenle dolaylı da olsa bu belgelerin tele çalışmaya dayanak oluşturduğu ve Sözleşme kapsamında yer alan hakların da bu çerçevede ele alınabileceği ifade edilmiştir. ${ }^{37}$

Evde çalışma işçinin işveren tarafından oluşturulan iş organizasyonu çerçevesinde iş görme borcunu evinde yerine getirmesi esasına dayalı yazılı olarak kurulan iş ilişkisidir. ${ }^{38}$

34 UŞAN Fatih, "Parça Başına Çalışmanın Hukukî Niteliği ve Parça Başına Çalışan İşçinin Sorumluluğu", Ankara Hacı Bayram Veli Üniversitesi Hukuk Fakültesi Dergisi, Cilt:4, Sayı: 2, 2000, s. 3-7.

35 SÜZEK, s. 268.

36 İNCİROĞLU, s. 217.

37 GÜMRÜKÇÜOĞLU BOZKURT, s. 157.

38 ÇELIK/CANIKLIOGĞLU/CANBOLAT, s. 231., İNCİROĞLU, s. 193. 
Türk Hukukunda evde çalışmaya ilişkin ilk yasal düzenleme İş Kanununun 14. maddesinde yer alan düzenleme değildir. TBK'nın “Evde Hizmet Sözleşmesi" başlığını taşıyan düzenlemesinde işverenin verdiği işi işçinin kendi evinde veya belirleyeceği başka bir yerde bizzat veya aile bireyleriyle birlikte ücret karşılığında yerine getirebileceği düzenlenmiştir. (md. 461) Ancak belirtilmelidir ki İK kapsamında düzenlenen evde çalışma ve TBK kapsamında düzenlenen evde hizmet sözleşmesi pek çok açıdan birbirinden farklılık göstermektedir. Bu farklılıklara ilişkin ayrıntılı bilgiye evde hizmet sözleşmesi başlığı altında değinilmeye çalışılacaktır.

İş Kanununda evde çalışma kapsamında yer alan düzenlemede işçi ve işveren arasındaki bağımlılık unsuruna açıkça yer verilmemişse de 14. maddede yer alan düzenlemede işçinin iş görme ediminin "işveren tarafından oluşturulan iş organizasyonu kapsamında” yerine getireceğinin belirtilmesi taraflar arasındaki bağımlılık unsuruna işaret etmektedir. Evde çalışmaya ilişkin talep işverenden gelebileceği gibi işçi de böyle bir talepte bulunabilir. Ancak evde çalışma talebi kimden geliyor olursa olsun talepte bulunulan taraf evde çalışma ilişkisine zorlanamaz. ${ }^{39}$

Evde çalışmanın usul ve esasları şu şekilde özetlenebilir. Bu çalışma türünde sözleşmeler yazılı olarak yapılmalıdır. Çalışma programının ne şekilde olacağını belirlemek çalışanın seçimine bırakılmıştır. Bu durum çalışanlar açısından avantajlı bir durumdur. Evden çalışma kapsamında çalışılan araç ve gereçlerin iş sağlığı ve güvenliği gereklerine uygun olmaları gerekir. AB Çerçeve Anlaşmasında bu duruma değinilmiş ve İş Kanununun 14. maddesinde yer alan düzenlemede de işverenin iş sağlığ1 ve güvenliği yükümlülüğüne yer verilmiştir. Ancak gerek Kanunda yer alan düzenleme gerekse Uzaktan Çalışma Yönetmeliğinde yer alan ve İş Kanununda yer alan düzenlemeyi tekrarlamaktan öteye gidememiş olan düzenleme eleştirilebilir durumlardan birisidir. (Yön. md. 12) Bu düzenlemeler kapsamında yer alan işveren yükümlülükleri sınırlı şekilde yorumlanmamalıdır. Bu çalışmanın ana konusu da söz konusu durum ile ilgili olduğundan bu duruma ilişkin daha açıklayıcı bilgi çalışmanın devamında verilmeye çalışılacaktır. Evden çalışan işçi, işyerinde çalışan işçilerin sahip olduğu haklardan mahrum bırakılamaz. Söz konusu durum 14. madde kapsamında da düzenlenmiş ve sözleş-

39 TUNCAY, A. Can, “Pandemi Gölgesinde Evden Çalışma.” İSGHD. Cilt: 18, Sayı: 69, 2021, s. 26. 
menin niteliğinden ötürü diğer işçilerden farklı işleme tâbi tutulamayacağ1 belirtilmiştir. Ancak düzenlemede böyle bir cümle olmasaydı dahi İş Kanununun 5. maddesi gereği işveren uzaktan çalışan işçiler ile diğer çalışanları arasında ayrımı haklı kılan bir neden olmadıkça farklı muamelede bulunamayacaktı.

Evde çalışma kapsamında İş Kanununda yapılan düzenlemeden önce çalışanların hukukî niteliği konusunda tartışmalar bulunmaktaysa da İK md. 14'te yapılan değişiklikten sonra uzaktan çalışan kimselerin işverenin iş organizasyonu içerisinde iş gerçekleştirdikleri takdirde işçi sayılacaklarına dair bir şüphenin bulunmaması gerekir. ${ }^{40}$

\section{Tele Çalışma}

"Telework", "Telecommuting", "remotework" gibi kavramlarla ifade edilen tele çalışma terimine ilk kez 1972 yılında "Washington Post" gazetesinde yayımlanan bir yazıda yer verilmiştir. Evde çalışmaya nazaran daha yeni sayılabilecek bir çalışma türü olan tele çalışmanın yapılmış pek çok tanımı bulunmaktadır. Tele çalışma; merkezi işyeri ya da üretim imkânlarından uzakta gerçekleştirilen bu nedenle çalışanları oradaki iş arkadaşlarıyla kişisel iletişim kurmaktan alıkoyan ve teknolojik aletlerin bu ayrılmayı kolaylaştırdığı çalışma türü olarak tanımlanabilir. Bu tanım dışında özetle işletme merkezi dışında genel olarak evde gerçekleştirilen bilgisayar veya haberleşme ağı ile işletmeyle bağlantı kurulan, işçinin işyerine olan bağımlılığının işveren ise denetiminin diğer çalışma türlerine nazaran daha az olduğu çalışma türüdür denielbilir. ${ }^{41}$

Uzaktan çalışmanın unsurlarının mesafe ve işverenin iş organizasyonu içerisinde iş görme olduğu belirtilmişti. Tele çalışmalarda bu unsurlara ek olarak teknoloji unsuru bulunmaktadır.

Evde çalışmanın modern türü olarak nitelendirilen tele çalışmada önemli olan işçinin erişilebilir konumda olmasıdır. Çalışan fiziki olarak

40 Öğretide çalışanların "işçi” olarak nitelendirilebilmesi için bağımlılık ilişkisinin varlığının tespit edilmesi halinde evde çalışanlara yalnızca İş Kanunu hükümlerinin aksi halde Borçlar Kanunu hükümlerinin uygulanması gerekliliğini savunan görüşün aksine Borçlar Kanununun hizmet sözleşmeleri çerçevesinde yer alan düzenlemelerinin atipik iş sözleşmelerini düzenlediği gerekçesiyle bu görüşe katılmanın mümkün olmadığı ifade edilmiştir. ŞAHİN Barış. Bireysel İş Hukuku Açısından Bilgi İşçileri. Ankara Üniversitesi Sosyal Bilimler Enstitüsü: Yayımlanmamış Doktora Tezi, 2016, s. 264.

41 KANDEMİR Murat, İş Hukuku ve Sosyal Güvenlik Hukuku Açısından Tele Çalışma. Legal Yayınevi, 2011, s. 40. 
olmasa bile sanal olarak işverenle temas halindedir ve işini adeta işyerindeymiş gibi sürdürmektedir. Esasen tele çalışma "evde çalışma" değil "evden çalışma" olarak kullanılması gereken bir terimdir. Evde çalışma "house work" eskiden beri çalışanın kendi evinden çalışmasıyken evden çalışma "work from home" işyerinde çalışan işçinin herhangi bir nedenle geçici ya da kalıcı surette çalışmasına evden devam etmesidir. Yaygın olarak kullanılan "home office" çalışma esasen bu durumu karşılamaktadır. Ancak bu çalışmanın ayırt edici özelliği tekrar belirtmek gerekir ki bilgi teknoloji aletleri kullanılarak yerine getirilmesidir. Bu nedenle evden çalışmanın mavi yakalılar için değil beyaz yakalılar için uygun olduğu öğretide savunulmuştur. ${ }^{42}$

Uluslararası Çalışma Örgütünün tele çalışmaya yönelik özel bir düzenlemesi bulunmamaktadır. Evde çalışanlara yönelik etkin bir koruma sağlamayı amaçlayan 177 sayılı sözleşme ve 184 sayılı tavsiye kararında açıkça tele çalışmadan bahsedilmemişse de her iki düzenlemenin evde çalışmayı kapsadığı ve dolaylı da olsa tele çalışmaya dayanak oluşturduğu böylelikle tele çalışmanın sözleşme tarafından sağlanan haklar kapsamında ele alınabileceği söylenebilir. ${ }^{43}$

2002 yılında AB düzeyinde Avrupa sosyal ortakları tele çalışma ile ilgili Çerçeve anlaşma imzalanmıştır. Bu çerçeve kapsamında tele çalışma; iş sözleşmesi kapsamında aynı zamanda işyerinde de gerçekleştirilebilecek bir işin işyeri dışında, iletişim teknolojileri kullanılarak, sürekli şekilde gerçekleştirilmesine olanak sağlayan iş organizasyonu olarak tanımlanmıştır. (md. 2) Çerçeve Sözleşmenin amaçları arasında hem esnekliği hem de iş güvencesini bir arada sağlayan, çalışma yerlerinin kalitesini yükselten ve engelli bireylerin de çalışma imkânlarını artıracak biçimde tele çalışmanın desteklenmesini sağlamak bulunmaktadır. Tele çalışmanın sosyal diyalog yoluyla gönüllülük esasına dayandığı ifade edildiği Sözleşmede çalışma şartları kapsamında kişisel verilerin ve özel hayatın gizliliğinin, iş̧̧inin sağlık ve güvenliğinin korunmasının ve oluşacak ekstra giderlerin işveren tarafından karşılanacağına ilişkin esaslar bulunmaktadır. ${ }^{44}$

Genel itibariyle tele çalışma kapsamında yapılan tanımlamalar çerçevesinde bağımlı çalışan ya da bağımsız çalışan gibi bir ayrıma gidilmese de çalışma konusunun iş hukuku olduğu göz önüne alınarak şu

\footnotetext{
42 TUNCAY, s. 26-28.

43 KANDEMİ, s. 50.

44 TUNCAY, s. 42.
} 
şekilde bir tanım yapılabilir. Çalışanların iş sözleşmesinden doğan edimlerini, düzenli bir şekilde, işverenlerin doğrudan gözetim ve denetimleri bulunmaksızın klasik işyeri dışında herhangi bir yerde, bilgi ve iletişim teknolojileri kullanılarak gerçekleştirilen çalışma şekli olarak tanimlama yapilabilir. ${ }^{45}$

Tele çalışmanın pek çok farklı türleri bulunmaktadır. Bu çalışma kapsamında bu türlere ilişkin ayrıntılı açıklama getirilmeyecektir. Gezici tele çalışma, tele merkezden çalışma, dönüşümlü tele çalışma, yerinden tele çalışma gibi çalışma türleri tele çalışmanın alt başlıklarını oluşturabilir. Bu açıdan işçinin işletme merkezinde olma zorunluluğunun olmadığı, işverenin iş organizasyonu ile bağlantısının bilgi iletişim teknolojileri kullanılarak sağlandığı her türlü çalışma tele çalışmadır. ${ }^{46}$

Uzaktan Çalışma Yönetmeliğinin taslak metninde uzaktan çalışma; "teknoloji esaslı uzaktan çalışma" veya "evde uzaktan çalışma" şeklinde ele alınmış ve teknoloji esaslı uzaktan çalışmanın tanımı yapılmışsa da yürürlüğe giren Yönetmeliğin 4. maddesinde, İş Kanununun 14. maddesinde yer alan tanım tekrarlanmakla yetinilmiş ve ayrıca teknoloji esaslı uzaktan çalışmaya ilişkin herhangi bir tanıma yer verilmemiştir.

Tele çalışmada işçi ile işveren arasındaki elektronik bağ genellikle çevrim içi olarak kurulmaktadır. Tele çalışmaya karakteristik özelliğini veren şey çalışmanın işyeri dışında evde ya da başka bir mekânda olması dışında çalışma türünün başında kullanılan "tele" ön eki sayesinde uzaktan gerçekleştirilen bu çalışmanın aynı zamanda bilgi ve iletişim teknolojileri kullanılarak yapıldığını ifade etmektedir. ${ }^{47}$ Ancak mekân ve teknoloji unsuru dışında tele çalışmayı karakterize eden bir diğer özellik çalışmanın sürekli ve düzenli olarak işverenin iş organizasyonu kapsaminda yapılmasıdır. ${ }^{48}$

Dijitalleşme sosyal ve ekonomik hayat üzerinde öylesine belirleyici rol oynamaktadır ki, dijitalleşmenin getirisi ile beraber "dördüncü sa-

\footnotetext{
45 KANDEMIR; s. 41.

46 DULAY YANGIN Dilek, “Bilgi ve İletişim Teknolojilerinde Yaşanan Gelişimin İş Hukuku Üzerindeki Etkileri: Tele Çalışmaya İlişkin Tespit ve Öneriler, (Tele Çalışma)" İş Hukukunda Genç Yaklaşımlar III. Editör: Tankut CENTEL, 2018, s. 225.

$47 \quad$ KANDEMIR, s. 39., İNCİROĞLU, s. 194.

48 ÇELIK/CANIKKLIOĞLU/CANBOLAT, s. 230.
} 
nayi devrimi"nin en önemli sonuçlarından birisi de işgücünün dijital platformlar aracılığıla yerine getirilmesidir. ${ }^{49}$

İş ilişkisi ve buna bağlı olarak kişisel bağımlılığın ortaya çıkıp çıkmadığı konusunda dijital platformlar aracılığıyla iş görenler arasında denetleme emir ve talimat verme olgusunun varlığının incelenmesi gerektiği belirtilmiştir. ${ }^{50}$

\section{Evde Hizmet Sözleşmesi}

Türk Hukukunda uzaktan çalışmaya ilişkin hükümler yalnızca İş Kanununda yer almamaktadır. Bu çalışmanın konusu uzaktan çalışma kapsamında işverenin iş sağlığı ve güvenliğini sağlama borcu olduğundan evde hizmet sözleşmesi kısaca tanıtıldıktan sonra bu sözleşmeler kapsamında işverenin işçiyi gözetme ve koruma borcunun görünümü açıklanmaya çalışılacaktır.

Türk Borçlar Kanununda düzenlenen "Evde Hizmet Sözleşmesi" de uzaktan çalışmanın ele alındığı bir diğer hukukî düzenlemedir. Evde hizmet sözleşmelerinin TBK kapsamındaki düzenlemesinde kaynak İsviçre Borçlar Kanununun 351. maddesi göz önünde bulundurulmuştur. ${ }^{51}$

TBK'nın üçüncü ayrımında ele alınan düzenlemenin ilk maddesinde evde hizmet sözleşmelerinin tanımı yapılmıştır. Buna göre;

“Evde hizmet sözleşmesi, işverenin verdiği işi, işçinin kendi evinde veya belirleyeceği başka bir yerde, bizzat veya aile bireyleriyle birlikte bir ücret karşılığında görmeyi üstlendiği sözleşmedir." (md. 461)

Hizmet sözleşmelerinin bir türü olan evde hizmet sözleşmelerinin genel hizmet sözleşmelerinden farkı, işçinin işini işverene ait işyerinde değil kendi evinde veya belirlediği başka bir yerde çalışarak meydana getirmesidir. Sözleşmeyi oluşturan unsurlardan birisi budur. Bu tür hizmet sözleşmelerinde hem işçinin hem de işverenin yararı vardır. İşçi

49 Esasında burada bahsedilen ve ilk defa 2011 yılında Hannover Fuarı'nda bahsedilen "Endüstri 4.0" kavramı özellikle tele çalışmadan daha farklı bir sistemi barındırmaktadır. Bu sistemde kendiliğinden özelliklere sahip akıllı sistemler ile üretim gerçekleştirilmekte ve insan emeği oldukça en alt seviyeye çekilmektedir. Hatta internet aracılığı ile birbirine bağlı araçlar sayesinde üretimin yapıldığı yerde hiçbir şekilde insan bulunmaması sebebiyle "Karanlık Fabrikalar" olarak da adlandırılmaktadir. DULAY YANGIN (Dijitalleşme), s. 1213.

50 DULAY YANGIN (Dijitalleşme), s. 1214-1215.

51 BAŞÖZ Lütfi, ÇAKMAKCI Ramazan, Türk Borçlar Kanunu, Legal Yayınevi, 2013, s. 534. 
açısından yararı, işe gidip gelmeden kendi evinden işini görmesi ile zamandan ve masraftan tasarruf etmesiyken işveren açısından yararı işyeri temin etme külfetinden kurtulması olarak gösterilebilir. ${ }^{52}$

Sözleşmenin diğer unsurları ise işverene bağımlılık, işin işçi veya aile bireyleriyle birlikte yapılması, çalışma koşullarının işveren tarafından belirlenmesi ve ücrettir. Bu unsurlardan işin işçi veya aile bireyleriyle yapılması unsuru, evde hizmet sözleşmelerinin diğer hizmet sözleşmelerinden ayrılan yönünü oluşturur. İşçinin işi bizzat ifa yükümlülüğü yoktur bu nedenle işçi işi aile fertlerine de yaptırabilir. ${ }^{53} \mathrm{Bu}$ durumda aile fertlerinin işveren karşısındaki hukukî niteliğinin ne olacağı belirlenmelidir. İş sözleşmesi karşılıklı olarak iki tarafa borç yükleyen sözleşmelerdir ve işçinin, işverene karşı yerine getirmesi gereken yükümlülükleri bulunmaktadır. İş görme edimini işçi ile beraber yerine getiren aile bireylerinin hukukî niteliğinin işçi olarak kabul edilmesi durumunda aile bireyleri de iş sözleşmesinin tarafı sayılacaktır. Bundan sonra sözleşmeden doğan her türlü hakkın sahibi ve borcun yükümlüsü say1lacaklardır. Ancak aile fertlerinin işçi olarak nitelendirilmesi ancak işverenle sözleşme yapmaları halinde mümkündür. Evde hizmet sözleşmesinin tanımında işçinin işi bizzat veya aile bireyleri ile görülebileceği belirtilmiştir. Bu durumda işverenle aralarında sözleşmesel bir ilişki bulunmayan aile bireyleri işçi sayılmayacaklardır. Öğretide aile fertleri borcun ifasına yardım eleman olarak nitelendirilmişlerdir. İşçinin işin ifasına yardım bireyler seçmesi ve verilen görevi serbestçe reddetme yetkisinin bulunmasının genel itibariyle bağımsız çalışmanın göstergesi olduğunu belirten görüşe göre evde çalışma açısından bu kıstaslara ihtiyatlı yaklaşılması gerektiği ifade edilmiştir. Evde hizmet sözleşmesi ile getirilen bu düzenleme iş sözleşmelerinde şahsen ifa kuralının istisnasıdir. ${ }^{54}$

Evde hizmet sözleşmelerinin geçerliliği için herhangi bir şekil şartı aranmaz. İş Kanununda düzenlenmiş uzaktan çalışmada ise sözleşmelerin yazılı olarak yapılması gerektiği düzenlenmiştir. Evde hizmet sözleşmelerinde yazılı olarak bildirim aranan haller vardır. Bunlar işçi tarafından sağlanacak malzeme, bu malzemenin sağlanması için işçiye ne miktarda ödemede bulunulacağı ve iş için ödenecek ücrettir. Bu hallere

52 KILIÇOĞLU Ahmet. M., Borçlar Hukuku Özel Hükümler, Gözden Geçirilmiş Güncelleştirilmiş 2. Bası, Turhan Kitabevi, 2020, s. 451.

53 KILIÇOĞLU, s. 452.

54 DULAY YANGIN, s. 156. 
ilişkin yapılacak bildirimin yazılı olması gerekir. Yazılı bildirim yoksa "bu işlerde uygulanan alışılmış bedel ve ücret" miktarında ödeme yapilması gerekecektir. ${ }^{55}$

Evde hizmet sözleşmeleri, ev hizmetleri ile karıştırılmaması gereken sözleşmelerdir. Ev hizmetleri evin gündelik işleyişine ilişkin faaliyetlerdir. Ev hizmetlerinde çalışanlar evde bulunan kimseler için iş görme edimini yerine getirirler. Ev hizmetlerinde çalışanların yaptıkları iş bedeni çalışmayı gerektirebileceği gibi özel sekreter, özel ders verme gibi fikri çalışmaları da içerebilir. ${ }^{56}$

TBK kapsamında tanımı yapılan evde hizmet sözleşmelerinde teknolojik iletişim aletlerinin kullanılmasından söz edilmemiştir. Bu nedenle bu tür sözleşmeler öğretide "geleneksel evde çalışma" olarak tanımlanmıştır. TBK genel kanun niteliğinde olduğundan, İş Kanununun 14. maddesinde düzenlenmemiş bir konu varsa bu durumda TBK md. 461 vd. hükümlerinin uygulanacağ 1 belirtilmiştir. ${ }^{57}$ Evde hizmet sözleşmelerine ilişkin kısımda hüküm bulunmayan hallerde ise TBK'nın genel hizmet sözleşmesine ilişkin kısımlar uygulanacaktır. Bu çalışma şekline İK hükümleri ile TBK hükümlerinin bir arada uygulanması gerekir. Hâkim önüne gelecek uyuşmazlıkta uygulanması gereken hükmü saptarken amaçsal yorum yapmalıdır. Özetle denilebilir ki evde hizmet sözleşmesi TBK kapsamında düzenlenmiş olsa dahi bu işçiler İK md. 4'te sayılan istisnalar kapsamına girmediği sürece bu işçilerin İK hükümlerine tâbi olunmasına engel bir durum bulunmamaktadır. Hâkim somut olayların özellikleri doğrultusunda hükümlerin konuluş amacına uygun olarak yorum yapmalıdır. ${ }^{58} \mathrm{Bu}$ husus evde hizmet sözleşmelerinin genel hizmet sözleşmesi niteliği taşımalarından kaynaklanmaktadır. ${ }^{59}$ Ancak öğretide tele çalışmaya, evde hizmet sözleşmesine ilişkin hükümlerin uygulanamayacağı, çalışma evde gerçekleştirilse dahi işçiye daha çok koruma sağlayan İş Kanunu hükümlerinin uygulanması gerektiği de savunulmuştur. ${ }^{60}$

\footnotetext{
$55 \quad$ YAVUZ, s. 539.

56 CIVAN Orhan Ersun, "İş Hukukunda Uzaktan Çalışma (Evde Çalışma/Tele Çalışma)", İş Hukuku ve Sosyal Güvenlik Hukuku Dergisi, Cilt: 7, Sayı: 26, 2010, s. 529.

57 TUNCAY, s. $45,46$.

58 DULAY YANGIN (Tele Çalışma), s. 229.

59 ÇELIK/CANIKLIOĞLU/CANBOLAT, s. 231., KANDEMİR, s. 157., GÜNAY, s. 185., KILIÇOĞLU, s. 451., YAVUZ, s. 538.

60 ALP, Mustafa, “Tele Çalışma (Uzaktan Çalışma)”, Prof. Dr. Sarper Süzek'e Armağan, 2011, s. 813. 795-851., Tele çalışmaya ilişkin yapılan bu ayrımın yerinde olup
} 
Evde hizmet sözleşmesinde işçi iş görme edimini klasik iş sözleşmelerinden farklı olarak işveren tarafından belirlenmiş bir yerde değil işçi tarafından seçilen bir yerde ve çoğunlukla kendi evinde yerine getirilmektedir. Bu durumda da işçi görmekte olduğu işini doğrudan işverenin denetim ve gözetimi altında olmaksızın görür. Bu durum işverenin işçi üzerinde herhangi bir denetimi olmadığı şeklinde yorumlanmamalıdır. İşverenin denetimi işin görülmesi esnasında değil işin sonucunda başka bir ifade ile işin tesliminde söz konusu olmaktadır. Böylelikle işçinin denetimi zaman bakımından ötelenmiş olmaktadır. ${ }^{61}$

Öğretide evde hizmet sözleşmelerinin klasik iş sözleşmelerinden ayrılan yönlerinden bir diğerinin işçinin işin sonucundan dolayı sorumluluğu konusunda olduğu ifade edilmiştir. Buna göre klasik iş sözleşmelerinde işçinin yapmış olduğu işin sonucundan sorumlu olmayacağı, işin kötü ifa edilmiş olmasının ücrete hak kazanmasını etkilemeyeceği ifade edilmiştir. Ancak bu görüşe göre evde hizmet sözleşmelerinde işçi tıpk1 eser sözleşmelerinde olduğu gibi işin sonucundan da sorumlu tutulacaktır. ${ }^{62}$

\section{Uzaktan Çalışma Kapsamında İşverenin İş Sağlı̆̆ ve}

\section{Güvenliğini Sağlama Yükümlülüğü}

Uzaktan çalışma kapsamında işveren bu çalışma türlerinin kendine özgü niteliklerinden doğan tehlikeleri ortadan kaldırmak amacıyla gerekli iş sağlığı ve güvenliği önlemlerini almakla yükümlüdür. İşin sınırları belirlenmiş olan işyeri dışında görülüyor olması işvereni iş sağlığ1 ve güvenliği sorumluluklarını almaktan kurtaramayacaktır. Ancak bu durum sorumluluğun kapsamını belirleme konusunda etkili olacaktır. ${ }^{63}$

olmadığının incelenmesi gerekir. Uzaktan çalışma alt başlığı altında ele alınan evde çalışma ve tele çalışma açısından hüküm bulunmayan hallerde evde çalışma için TBK hükümleri, tele çalışma için İş Kanunu hükümlerini uygulama şeklinde bir ayrıma gitmek isabetli değildir. İş Kanununda hüküm bulunmayan hallerde Borçlar Kanununda yer alan düzenlemeler boşluk doldurucu bir şekilde ve bilhassa özel hükümlerin söz konusu olduğu durumlarda uygulanma alanı bulmalıdır şeklindeki görüş doğrultusunda hareket etmek hukuka uygundur. SÜZEK, s. 270.

61 GÜLVER Ender, “Türk Borçlar Kanununun Evde Hizmet Sözleşmesine İlişkin Hükümleri Üzerine", IÜHFM., Cilt: LXXII, Say1: 2, 2014, s. 105.

62 GÜLVER, s. 104.

63 DULAY YANGIN (Tele Çalışma), s. 230. 
Uzaktan çalışma kapsamında işverenin iş sağlığı ve güvenliği yükümlülüğü anlatılmaya çalışılırken konu birkaç farklı açıdan ele alınmaya çalışılacaktır. İş Kanununun 14. maddesinde yer alan uzaktan çalışma kapsamında evde çalışma veya tele çalışma kapsamında iş görme edimini yerine getiren kişinin şahsen ifa yükümlülügüünden bahsedilmişti. İş sağlığ1 ve güvenliği yükümlülüğü kapsamında işverenin bu edimi yerine getiren işçilere karşı yükümlülüğü ilgili maddede ve Uzaktan Çalışma Yönetmeliğinde açılanmıştır. Ancak bu konu açısından ele alınması gereken özellikli durumlardan birini evde hizmet sözleşmesi kapsamında bizzat veya aile üyeleri ile iş görme edimini yerine getiren işçinin yakınlarının iş sağlığı ve güvenliğinden işverenin ne derece ve hangi kurallar çerçevesinde sorumlu tutulacağıdır. Bir diğer durum ise uzaktan çalışma kapsamında meydana gelen sağlık ve güvenliği olumsuz etkileyen bir durumun iş gören kişiler dişında evde yaşayan diğer kişileri etkilemesi halinde işverenin sorumluluğudur. Çalışmanın devaminda İK kapsamında uzaktan çalışanların, TBK kapsamında uzaktan çalışanların, TBK kapsamında uzaktan çalışanların iş görme edimine yardımcı olan kimselerin ve son olarak uzaktan çalışma esnasında işin görüldüğü yerde özellikle evde bulunan kimselerin iş sağlı̆̆1 ve güvenliğinden işverenin sorumluluğu, sorumluluğunun sınırları açılanmaya çalışılacaktır.

\section{a. İş Kanunu Kapsamında Uzaktan Çalışan İşçilerin İş Sağlığı ve} Güvenliğini Sağlama Yükümlülüğü

4857 sayılı Kanunda işverenin uzaktan çalışma kapsamında işin niteliğine uygun olarak iş sağlığ 1 ve güvenliği önlemlerini almakla yükümlü olduğu ifade edilmiştir. Kanunda yer alan düzenleme Uzaktan Çalışma Yönetmeliğinin 12. maddesinde de aynı şekilde tekrar edilmiş ve "İ̧sveren, uzaktan çalışanın yaptığı işin niteliğini dikkate alarak iş sağlığı ve güvenliği önlemleri hususunda çalışanı bilgilendirmekle, gerekli eğitimi vermekle, sağlık gözetimini sağlamakla ve sağlad1ğ1 ekipmanla ilgili gerekli iş güvenliği tedbirlerini almakla yükümlüdür" denilerek işverenin yükümlülükleri sayılmıştır.

İşverenin iş sağllğ 1 ve güvenliği önlemleri hususunda bilgilendirilmesi çalışanların temel haklarından ifade özgürlügünün bir parçasıdır. ${ }^{64}$ İSGK md. 16 kapsamında işverenin bilgilendirme yükümlülüğü

64 ÖZDEMİR Erdem, İş Sağlığı ve Güvenliği Hukuku Dersleri, Vedat Kitapçılık, 2020, s. 147. 
düzenlenmiştir. İşverenin bu yükümlülüğüne aykırı davranması neticesinde iş kazası veya meslek hastalığı meydana gelmişse bu durum işverenin kusurunun belirlenmesinde dikkate alınır. ${ }^{65}$

Gerek Kanunda gerekse Yönetmelikte sayılan işverenin İSG yükümlülükleri sınırlı sayıda değildir. Tüm bunlar dışında işveren yapılan işin niteliğini dikkate alarak çalışanlara İSG yönünden uygun makine, ekipman, araç, gereç vermekle, gerekiyorsa sağlık raporu almadan işçiyi işe başlatmama yine aynı biçimde gerektiği takdirde mesleki eğitim belgesi olmadan iş vermeme, meydana gelen iş kazası ve meslek hastalıklarını süresinde ilgili birimlere bildirmekle yükümlüdür. ${ }^{66}$ İşverenin bilgilendirme yükümlülüğ̈̈ durağan değildir. Bu nedenle bu yükümlülük sürekli gözden geçirmeyi gerekli kılabilir. Her ne kadar Kanunda gerekli olduğunda bilgilendirmenin tekrar edilebileceği ifade edilmemişse de öğretide isabetli olarak yapılan işin niteliğinin değişmesi veya iş ile ilgili yeni tehlikelerin ortaya çıkması halinde işverenin bu yükümlülüğünü tekrarlaması gerektiği ifade edilmiştir. ${ }^{67}$

İşverenin bilgilendirme yükümlülüğünün ihlali hali İSGK md. 26/1-g hükmünde düzenlenmiştir. İşverene bilgilendirilmeyen her bir çalışan için idari para cezası yaptırımı uygulanacaktır. Bu açıdan çoğunlukla kolektif bir şekilde yerine getirilmesi gereken yükümlülük her bir çalışan ayrı ayrı ele alınarak yaptırıma bağlanmıştır. Ayrıca işverenin hukukî sorumluluğunun belirlenmesinde bilgilendirme yükümlülüğünün ihlali önemli bir yer tutmaktadır. Tarafların kusurunun tespitinde en etkili unsurlardan birisinin bilgilendirme yükümlülüğü olduğu ifade edilmiştir. ${ }^{68}$

İşverenin gerekli eğitimi verme yükümlülüğü Kanunda sayılan diğer bir yükümlülüktür. Bilgilendirme yükümlülüğü ve eğitim verme yükümlülüğü birbirine karıştırılmaması gereken yükümlülüklerdir. İşverenin bilgilendirme yükümlülüğü tek taraflıdır, çalışanları ölçme ve değerlendirme söz konusu değildir. ${ }^{69}$ Eğitim verme yükümlülüğü kapsamında çalışanlar almış oldukları eğitim doğrultusunda karşılaşabile-

65 SÜMER Halûk Hâdi, İş Sağlığı ve Güvenliği Hukuku (İş Sağlığı ve Güvenliği), Güncellenmiş 4. Baskı, Seçkin Yayıncılık, 2020, s. 156, 157.,

66 İNCİROĞLU, s. 227., ÇELİK/CANIKKLIOĞLU/CANBOLAT, s. 233.

67 CANIKLIOĞLU Nurşen, “6331 Sayılı İş Sağlı̆̆1 ve Güvenliği Kanununda Öngörülen İşveren Yükümlülükleri, Çalışma Mevzuatı Seminer Notları” Toprak İşveren Yayınları, 2013, s. 67., ÖZDEMİR, s. 151.

68 ÖZDEMIR, s. 152.

69 ÖZDEMIR, s. 148. 
cekleri sağlık ve güvenlik tehlikelerini bertaraf edebileceklerdir. İşin özenle ifası için çalışanların aldıkları eğitimleri dikkatle takip etmeleri gerekir.

ILO'nun 155 sayılı Sözleşmesi ortaya çıkabilecek iş sağlığı güvenliği problemlerinin çözümü için tüm çalışanların eğitim ihtiyacını karşılayacak seviyelerde eğitim verilmesi gerekliliğine değinilmiştir. (md. 14) İSK md. 17 kapsamında çalışanlara verilmesi gereken eğitim yükümlülügünden söz edilmiştir. Söz konusu düzenlemenin amacı iş sağlı̆̆ı ve güvenliği kültürünün oluşması ile beraber çalışanlara karşılaşabilecekleri tehlikeli durumlarda uymaları gereken kuralları öğretmektir. Çalışanların İş Sağlığı ve Güvenliği Eğitimlerinin Usul ve Esasları Hakkında Yönetmelik ${ }^{70}$ kapsamında da işçinin sözleşmesinin türüne bakılmaksızın işverenin eğitim verme yükümlülügüne ilişkin kurallar düzenlenmiştir. Söz konusu Yönetmelikte çalışanlara verilecek eğitimin uzaktan da yapılabileceği düzenlenmiştir. Böylelikle evde çalışan ya da işyeri dışında herhangi bir yerde tele çalışan işçiler işverenin vereceği eğitimi uzaktan alabileceklerdir. (md. 12/7)

Yargıtay tarafından verilen kararda çalışanların eğitimi ve bilgilendirilmesi hususunda şu ifadelere yer verilmiştir. "İş güvenliği önlemleri alma, kişisel güvenliği sağlama hususundaki inisiyatifin tek başına işçiye bırakıldığı, çalışılan ortam nedeniyle oluşan tehlikeler konusunda yeterli bilgi verilmediği görülmektedir. İş sağlığı, iş güvenliği ve yapılmakta olan iş nedeniyle işçilerin eğitimi, bir kısım mevzuatı içerir belgelerin kendilerine verilmesiyle değil, eylemli olarak bu bilgilerin aktarımı ve öneminin kavratılması ile sağlanabilir. Eğitimden sonraki aşama ise iş sağlığı ve güvenliğiyle ilgili önlemlerin uygulandığının denetlenmesidir." 71

Çalışanların evde çalışma kapsamında veya tele çalışma kapsamında kendileri dışındaki kimselerin sağlık ve güvenliğini tehlikeye düşürmeme yükümlülüğünün sınırlarını, iş sağlı̆̆ı ve güvenliği konusunda aldıkları eğitim ve işverenin bu konudaki talimatları oluşturacağından işverenin eğitim verme yükümlülüğü karşılığında çalışanlara da alınan eğitimlerde verilen talimatlara uyma yükümlülüğü içerir. Bu açıdan işveren tarafından aldırılmayan, eksik aldırılan ya da usulüne uygun olmayan bir eğitim söz konusuysa çalışanın yükümlülükleri darala-

$70 \quad$ RG. $15.05 .2013,28648$.

71 YHGK. 16.06.2004, 21/365, 369. ÜÇIŞIK Hasan Fehim, İş Sağlığı ve Güvenliği Hukuku, Ötüken Yayınevi, 2021, s. 152. 
caktır. Yargıtay tarafından verilen kararda da işçilerin iş sağlığı ve güvenliği yükümlülüklerini ihlal edip etmediklerinin tespitinde bu konuda eğitim alıp almadığı ya da yapmadığı iddia edilen eylemlerin görevi kapsamına girip girmediğinin tespit edilmesi gerekir. ${ }^{72}$

Yargıtay tarafından verilen başka bir kararda iş sağlığı ve güvenliği ve yapılmakta olan iş nedeniyle işçilerin eğitimi, mevzuat hükümlerini içeren belgelerin verilmesini değil, eylemli olarak bilgilerin aktarımı ve öneminin kavratılması ile sağlanabilir. Eğitimden sonra ise iş sağlığı ve güvenliği ile ilgili önlemlerin alındığının ve uygulandığının denetlenmesi gelir. ${ }^{73}$

Eğitim verme yükümlülügünün ihlali hali için bilgilendirme yükümlülüğünde olduğu gibi her bir çalışan için ayrı ayrı idari para cezası yaptırımı öngörülmüştür. 6331 sayılı İş Sağlığı ve Güvenliği Kanunu (İSGK) $)^{74}$ md. 26/1-ğ de ele alınan düzenleme kapsamında eğitim yükümlülüğü her bir çalışan için ayrı ayrı hesaplandığında işverenler açısından yüklü maliyetler söz konusu olabilecektir. Bu nedenle işverenlerin yükümlülüklerini yerine getirmesi konusunda daha hassas olmaları gerekecektir. İşverenin hukukî sorumluluğunun belirlenmesi konusunda da eğitim verme yükümlülüğü önemli bir yer tutmaktadır. Yargıtay tarafından verilen kararda tarafların kusur oranlarının belirlenmesi süreçlerinde işçilere eğitim verilip verilmediğinin incelenmesi gerektiği belirtilmiştir. ${ }^{75}$

İşverenin sağlık gözetimini sağlama yükümlülüğü içerisinde pek çok yükümlülüğü barındıran oldukça geniş kapsamlı bir yükümlülüktür. İşverenin bu yükümlülüğü uzaktan çalışma sözleşmesine uygulanabildiği ölçüde vardır. Bu nedenle sağlık gözetimini sağlama yükümlülüğü her iş ilişkisi için ayrı ayrı ele alınmalıdır.

Çalışanların sağlığının korunması ve geliştirilmesi, mesleki olumsuz etkilenmeleri önlemek amacıyla tıbbi muayene ve tetkikleri, çalışanların ortamdaki riskler ile bunlara yönelik koruyucu tedbirler konusunda bilgilendirmenin yapılması, çalışma ortamındaki genel hijyen şartlarına yönelik inceleme gibi hususları içeren yükümlülük kapsamında aynı zamanda tüm çalışanların sağlık kayıtlarının kişilik hakları çerçeve-

\footnotetext{
72 Yarg. 22. HD. 11.10.2017, E: 2017/40712, K: 2017/21420. BAYSAL Ulaş. Çalışanların İş Sağlığ1 ve Güvenliği Yükümlülükleri. Beta Yayınevi, 2019, s. 54.

73 Yarg. 10. HD. 12.10.2017, 18734/6745., SÜMER (İş Sağllğı ve Güvenliği), s. 149.

$74 \quad$ RG. 30.06.2012, 28339.

75 Yarg. 10. HD. 18.03.2013, E: 2012/9266, K: 2013/5083, ÖZDEMİR, s. 168.
} 
sinde gizli tutulmasını da kapsar. ${ }^{76} 6331$ sayılı ISGK md. 15 kapsamında işverenin sağlı gözetimini sağlama yükümlülüğü düzenlenmiştir. Bu açıdan işe giriş esnasında, görülmekte olan işte değişiklik olması halinde, çalışanların uğrayacağı iş kazası ve meslek hastalıklarından sonra işe dönmeleri ile beraber talep etmeleri halinde işveren çalışanların sağlık muayenelerini yapmak zorundadır. İşverenin sağlık gözetimini yapma yükümlülüğüne aykırı davranmasının yaptırımı İSGK md. 26/1-f kapsamında düzenlenmiştir. Bu yükümlülügüünü yerine getirmeyen işverene her çalışan için ayrı ayrı idari para cezası yaptırımı uygulanacaktır.

Sağlık gözetimi yapma yükümlülüğü konusunda göz önüne alınması gereken hususlardan birisi de işverenin kusurunun belirlenmesinde meydana gelen hastalık veya kaza ile sağlık gözetimi yükümlülüğü arasında illiyet bağının olmasıdır. Yargıtay tarafından verilen kararda işveren tarafından yalnızca sağlık raporunun alınmamış olması ve çalışanların yıllık sağlık kontrollerinin yerine getirilmemiş olması halinin işverenin kusur oranının \%60 olarak belirlenmesinde yeterli görülmemiştir. ${ }^{77}$

Sağlık gözetiminin sağlanması yükümlülüğü her ne kadar meslek hastalıklarının önlenmesi gibi bir misyon üstlense de esasında iş kazalarının azaltılmasıyla da oldukça bağlantılı bir kavramdır. Sağlık gözetimleri neticesinde yapacağ çalışanların işleri değiştirilmek suretiyle iş kazaları ve meslek hastalıklarının önüne geçilebilir. ${ }^{78}$ Örneğin tele çalışma kapsamında bilgi teknoloji aletleri kullanarak iş görme edimini yerine getirecek olan çalışanın göz muayenesi işverenin sağlık gözetimi yükümlülüğü kapsamında yerine getirilmelidir. Aksi halde çalışan kimsede görme bozuklukları ile bağlantılı olarak ileride başka pek çok sağlık sorunu ortaya çıkabilir. Söz konusu durum çalışan kişinin yalnızca çalışma hayatını değil günlük yaşamını da olumsuz etkiler.

İşverenin uzaktan çalışma kapsamında İş Kanununda sayılan yükümlülüklerinden bir diğerini sağladığı ekipmanlarla ilgili iş güvenliği

76 ÜÇIŞIK, s. 150.

77 Yarg. 21. HD. 23.12.2009, E: 2008/16956, K: 2009/21076. Yargitay tarafından verilen başka bir kararda da çalışanların sağlık gözetimini sağlama konusunda alınacak herhangi bir raporun değil işin niteliğine uygun standartlarda alınması gereken raporun sorumluluğun belirlenmesinde önemli olacağı belirtilmiştir. Yarg. 10. HD. 03.10.2011, E: 2011/12363, K: 2011/12963., ÖZDEMİ, s. 143.

78 ÖZDEMIR, s. 137. 
tedbirleri almak oluşturmaktadır. Söz konusu tedbirleri almak işverenler için yükümlülük olmanın yanı sıra çalışanlar içinde aynı zamanda iş sağlığı ve güvenliğinin sağlanması noktasında yükümlülük oluşturmaktadır. Çalışanın kendisine verilen aracı doğru kullanmaması nedeniyle iş kazası meydana gelirse bu durum çalışanın kusur durumunu etkileyecektir. Kişisel Koruyucu Donanımların İşyerlerinde Kullanılması Hakkında Yönetmeliğin79 "Kullanım Kuralları" başlıklı 8. maddesinde çalışanların 6331 sayılı Kanuna uygun olarak iş sağlığı ve güvenliği kapsamında aldıkları eğitim ve işveren talimatları doğrultusunda kişisel koruyucu donanımları doğru kullanmakla yükümlü oldukları bildirilmiştir. Elbette çalışanların bu yükümlülüğü işverenlerin sağladığı ekipmanlarla ilgili iş güvenliği tedbirleri almasının sonucu olarak ortaya çıkacaktir.

İşverenin önlem alma yükümlülüğünün sınırını ev çalışmalarının niteliği gereği yerine getirme imkânına sahip olduğu tüm yükümlülükler oluşturur. Ancak işverenin iş sağlığı ve güvenliği yükümlülüklerini yerine getirirken işçinin alınan bu yükümlülüklere uygun davranıp davranmadığını kontrol etmesi oldukça sınırlıdır. Çalışma yerinin denetimi bu durumda Anayasa ile güvence altına alınmış konut dokunulmazlığı ve özel hayatın gizliliği gibi hakları ihlal etme riskini de beraberinde getirecektir. Bu nedenle işveren tarafından gerçekleştirilecek denetimin bu haklar ekseninde ölçülü olması gerekir. Öğretide de işverenin iş sağlığ1 ve güvenliği kapsamında yapacağ 1 denetim çerçevesinde işçiden önceden rıza almış olsa bile her denetim öncesinde tekrar rıza alması gerektiği belirtilmiş ve denetimin dürüstlük kuralları gereği işçiye önceden haber verilmiş olması savunulmuştur. İşveren tarafından gerçekleştirilecek denetime ilişkin tüm belgelerin yazılı olması gerektiği, teftiş sınırlarının konut dokunulmazlığı ve özel hayatın gizliliğini korumaya yönelik anayasal ve yasal düzenlemeleri ihlal etmemesi gerektiği belirtilerek; teftiş ve denetimin yalnızca iş sağlı̆̆ 1 ve güvenliği ile sınırlı olarak yapılması ifade edilmiştir. ${ }^{80}$

Denetim amaciyla konuta erişim talebi işverenden gelebileceği gibi devletin teftiş ve denetim ile yetkili kılınmış müfettişlerinden de gelebilir. Bu açıdan talebin kimden geldiği önemli olmaksızın konuta erişim talebi, orantılılık ilkesine uygun olmalı ve denetimde bulunmanın gerektirdiği yer ve süre ile sınırlı olmalıdır. Örneğin bilgisayarla evin herhan-

\footnotetext{
79 RG. 02.07.2013, 28695.

80 DULAY YANGIN (Tele Çalışma), s. 234.
} 
gi bir odasından çalışmasını gerçekleştiren işçinin iş sağlı̆̆ı ve güvenliği denetimi açısından çalışılmayan odaların denetlenmesinde hukukî bir yarar bulunmamaktadır. Söz konusu durumda ölçülülük ilkesi de ihlal edilmiş olacaktır.

Uzaktan çalışma kapsamında işverenin yapacağı denetimlerde özellik arz eden durumlardan birini de tele çalışma kapsamında çalışmanın gerçekleştirildiği teknolojik aletlerin denetimidir hiç kuşkusuz. İşverenin işyerinde denetleme yetkisinin bulunduğu konusunda bir şüphe yoktur hatta işyerlerindeki iş organizasyonlarının karmaşıklığı, işlerin geniş bir alana yayılması ve işyerinde eş zamanlı pek çok faaliyetin yürütülmesi gibi nedenlerden dolayı en başta güvenliğin sağlanması için denetim zorunludur. İş hukukunda güvenlik ile ilgili anlaşılması gereken şey en başta işçilerin iş sağlığ manda bilgi ve veri güvenliği de işverenin bu noktada denetim yetkisinin gerekçesini oluşturmaktadır. ${ }^{81}$ İşverenin, işçilerin ya da üçüncü kişilerin sağlık ve güvenliğini sağlama gibi üstün bir yarar ya da kanundan doğan bir yükümlülükten işçilerin hak ve özgürlüklerine müdahale edebileceği kabul edilmektedir. ${ }^{82}$

Meşru gerekçelere dayalı olarak gerçekleştirilen denetimin işçilerin hak ve özgürlükleri ile çatışabileceği de bir gerçektir. ${ }^{83}$ İşverene sağlanan bu denetim yetkisi işçinin kişisel yaşamına müdahale imkânı vermemelidir. Aksi halde işçi ve işveren arasındaki bağımlılık ilişkisinin kölelikten bir farkı kalmayacaktır. Bu nedenle işverenin güvenlik gibi gerekçelere dayanarak gerçekleştireceği denetimin hukuka uygun sayılması için işçilerin önceden bilgilendirilmesi gerekir. Avrupa İnsan Hakları Mahkemesi (AİHM) tarafından verilen kararda da "internet, eposta- ya da telefon kullanımının izlemeye konu olabilmesinin koşullarından birisi işçilerin önceden bilgilendirilmesidir. Bu bilgilendirmenin yapılmaması durumunda çalışanlarla iletişimin gizliliği hususunda ma-

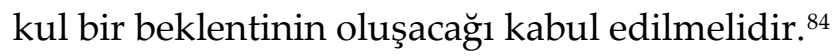

81 UGAN ÇATALKAYA Deniz, İş Hukukunda Ölçülüliük İlkesi, Beta Yayınevi, 2019, s. 298.

82 BAYRAM Fuat, Türk İş Hukukunda İşçinin Kişilik Hakkını Koruma Borcu, Marmara Üniversitesi Sosyal Bilimler Enstitüsü Yayımlanmamış Doktora Tezi, 2011, s. 37.

83 OKUR, Zeki, “Yeni Teknoloji ve İş Hukuku”, Çimento İşveren Dergisi, Cilt: 20, Sayı: 3, 2006, s. 4.

84 AïHM, Halford c. Royaume-Uni, 20605/92, 25.6.1997. UGAN ÇATALKAYA, s. 299. 
İşçinin iş görme edimini yerine getirirken teknolojik aletlerden yararlanması özellikle bağımlılık ilişkisini ve tarafların sahip olduğu hak ve özgürlükleri etkilemektedir. İşçinin iş görme esnasında kullandığ araçlar işçiyi özerkleştirmektedir. Ancak işyerindeki bilgi akışı ve talimat verme yöntemleri üzerinde de etkili olduklarından işyerlerinin organizasyonel yapılarını da etkilemektedir. Teknolojik çalışmaların getirisi olan özerklik ve bağımlı çalışmanın uğradığı değişim esasında özgürlüklerin lehine de olsa özünde iş yaşamı ve kişisel yaşam arasındaki ilişkinin silikleşmesi, işçiyi özel hayatından olumsuz etkileyebilecektir. Teknolojinin iş hayatında kullanımı işçiye özerklik sağlarken, işverenin denetim olanaklarını güçlendirmektedir. Bu açıdan işverenin iş̧̧iyi denetlemesi kapsamında hâkim tarafinda yapılacak incelemelerde denetlemeye esas olan gerekçelerle gizliliğin ihlali kavramının birbiriyle karıştırılması bilgi teknolojilerinin, özgürlükleri ve özerkliği büyük bir tehlikeye dönüştürebilecektir. Bu açıdan hâkimin, işverenin yetkisini hangi amaçla kullandığı konusundaki denetimini güçlendirmelidir. Bu açıdan işveren tarafından denetim konusunda izlenen amacın meşru olması ve iş̧̧inin önceden bilgilendirilmiş olması yeterli olmayacaktır. Aynı zamanda işveren tarafından izlenen amaca daha az müdahaleci bir yöntemle ulaşmanın imkân dâhilinde olup olmadığı da inceleme konusu yapılmalıdır. İşverenin bu açıdan yetkilerine yön verirken hukukun temel gerekleri göz önünde bulundurulmalıdır. "İşin insancıllaştırılması" ilkesi de bu yaklaşımın bir sonucudur. ${ }^{85}$

Bu kapsamda tele çalışmaya ilişkin Çerçeve Anlaşma kapsamında işverenin sorumluluğuna ilişkin genel ilkeden başka, tele çalışana bilgi verme yükümlülüğü ve işverenin denetim yetkisini kullanmanın usulüne ilişkin asgari normlar düzenlenmiştir. (md. 8)

Uzaktan çalışma Yönetmeliği'nin hazırlanan taslak metninde "İş Sağllğı ve Güvenliği Önlemlerinin Alınması" başlıklı 14. madde, İş Kanununda yer alan iş sağlığı ve güvenliğine ilişkin düzenlemeyi ele aldıktan sonra "...(2) işveren uzaktan çalş̧ma iliş̧isiyle iş verdiği iş̧̧iye iliş̧kin önleme politikası oluşturur. İşçi ise verilen talimatlar ve eğitimler doğrultusunda işverenin oluşturduğu politikaya uyar. (3) işveren, risk değerlendirmesi gerçekleştirmek, alınan önlemlere ilişkin iş̧̧iyi bilgilendirmek, gerekli eğitimi vermek, sağllk gözetimini să̆lamak ve sağladı̆̆ tüm iş araçlarının iş gereksinimleri ile iş sağlı̆̆ı ve güvenliğ̀i ve mevzuatı standartlarına uygun olmasinı sağlamakla yükümlüdür. (4)iş̧̧i meydana gelen iş kazaları, ramak kala olayları ve 
yürüttüğ̈̈ işi ile ilgili olduğundan şüphelendiği sağlık problemlerini işverene bildirir. Bunların kaydının tutulması, gerekli incelemelerin yapılarak raporlarnın düzenlenmesi ve gerekliyse yetkili mercilere bildiriminin yapılmasindan ise işveren sorumludur. (5) İş̧i kendisinin ve hareketlerinden veya yaptıkları işten etkilenebileceklerin sağllk ve güvenliğini tehlikeye düşürmemekle yükümlüdür" şeklinde yer verilen hüküm Yönetmelik kapsamına alınmamıştır. Yönetmelikte yer alan hüküm, İş Kanununda yer alan hükmü tekrarlamaktan öteye de gidememiştir. Esasen böyle bir yaklaşımın neden yapıldığını anlamak gerek iş sağlı̆̆ı ve güvenliğinin sağlanması gerekse iş teftiş ve denetimi konusunda çok yeterli olmayan ülkemiz açısından pek mümkün değildir. Her ne kadar Yönetmelik metnine, Taslak metninde yer alan bu hükümler alınmamış olsa dahi tüm sayılan hallerden işverenin sorumlu olduğu konusunda bir şüphe yoktur. Bu düzenlemelere yer verilmemiş olmasını işverenin anılan hallerden dolayı sorumlu olmayacağ1 şeklinde yorumlamak mümkün değildir. Söz konusu yükümlülükler zaten 6331 sayılı İSGK kapsamında işverenin yükümlülükleridir. Bu açıdan yapılan iş sözleşmesinin türlerine ilişkin de herhangi bir ayrıma gidilmemiştir. Ancak Yönetmelik metninin kırpılmaksızın taslak halinde olduğu şekli ile yürürlüğe girmesi sorumlulukların bir kez daha vurgulanması açısından daha yerine olacaktı.

Uzaktan çalışma kapsamında gerçekleştirilen işler doğrultusunda işçiler pek çok riske maruz kalmaktadır. Özellikle tele çalışma kapsamında gerçekleştirilen işlerde bilgisayarlı ekranlara maruz kalarak iş görenlerin iş sağlığı ve güvenliği pek çok açıdan olumsuz etkilenebilmektedir.

Mevzuatımızda da yer alan "Ekranlı Araçlarla Yapılan İşlerde Asgari Sağlık ve Güvenlik Gerekleri Hakkında 90/270/EC sayılı AB Yönergesi"ne ${ }^{86}$ uygun olarak hazırlanan Ekranlı Araçlarla Çalışmalarda Sağlık ve Güvenlik Önlemleri Hakkında Yönetmelik ${ }^{87}$ özel bir önem arz etmektedir. Söz konusu Yönetmelik tele çalışan kimseler açısından işverenin iş sağlığ1 ve güvenliğini sağlama yükümlülügüüü spesifik olarak düzenleyen metin olarak ifade edilmiştir. ${ }^{88}$ Yönetmelik ile beraber tele çalışma

86 Yönerge kapsamında işverenin yükümlülüklerine değinilmiş ve işçinin çalışmasını belirli aralıklarla ara verilecek ve ekran üzerindeki çalışma yükünü azaltacak şekilde düzenlemekle yükümlü olduğu ifade edilmiştir. Çalışanların görme sorunu söz konusu olduğunda bu kişilere görme testine tabi tutulma zorunluluğu da Yönerge ile getirilen düzenlemelerdendir. (md. 9)

87 RG.16.04.2013, 28620.

88 KANDEMIR, s. 132. 
kapsamına yönelik belirli standartlar getirildiği görülmektedir. Kullanılan teknik araçların belirli, 1sı, radyasyon ve gürültü seviyesini aşmaması, işçiler tarafından kullanılacak bilgisayar programlarında kullanılacak kriterler, çalışma ortamındaki uygun aydınlatma seviyesi, kullanılacak çalışma yüzeyi, çalışma sandalyelerine yönelik asgari standartlar, çalışanın göz ve beden sağlığı açısından işverenin bilgilendirme ve eğitim verme yükümlülüğü gibi durumlar Yönetmelik kapsamında ele alınan konulardandır.

Uzaktan çalışmada iş sağlığ1 ve güvenliği konularında ele alınması gereken durumlardan birisi de iş kazası ve meslek hastalığıdır. Uzaktan çalışan kimselerin çalışmaları esnasında meydana gelen olay neticesinde kazaya uğramaları durumunda bunun iş kazası sayılıp sayılmayacağı hususu tartışmalı olarak ifade edilmiştir. 5510 sayılı Kanun ${ }^{89}$ bilindiği üzere iş kazasının tanımını oldukça geniş bir şekilde ele almıştır ve hangi hallerde işçinin uğrayacağı kazanın iş kazası sayılacağı sayılmak suretiyle belirlenmiştir.

Klasik iş ilişkilerinde geleneksel manada işyerinde meydana gelen kaza, kazaya uğrayan kimsenin mesleki faaliyetini gerçekleştirdiği sırada gerçekleşir. Ancak uzaktan çalışmada zaman ve mekân kavramlarının geleneksel anlamını yitirmesi ile beraber işçinin meslek hayatı ve özel hayatı arasındaki sınır da belirsizleşebilmektedir. ${ }^{90} \mathrm{Bu}$ açıdan evde çalışan kimselerin uğrayacağı her kaza iş kazası olarak nitelendirilmeyecektir. Ancak çalışan kimsenin yapılan iş nedeniyle ve işin ifası sırasında uğradığı kaza iş kazası olarak kabul edilmelidir. Bu açıdan işverenin yükümlülügü evden veya uzaktan çalışan kimselere görülecek iş hakkında bilgi vermekte ve gerekli eğitimleri almasını sağlamaktır. Bu açıdan uzaktan çalışma kapsamında kullanılacak araç ve gereçlerin kullanımına dair verilecek eğitim de önemlidir. ${ }^{91}$

Özellikle tele çalışma kapsamında sabit bir yerde kalmaksızın işini ifa eden gezici tele çalışmalarda meydana gelen kazaların iş kazası sayılıp sayılmaması bakımından 5510 sayılı Kanunun iş kazası ile ilgili şu hükmü uyumludur. "Sigortalıların, işverence sağlanan bir taşıtla işin yapıldığı yere gidiş gelişi sırasında, meydana gelen ve sigortalıyı hemen veya sonradan bedenen ya da ruhen engelli hâle getiren olaydır." (md.

\footnotetext{
89 RG. 16.06.2006, 26200.

90 DULAY YANGIN (Tele Çalışma), s. 235.

91 KURT Resul, 250 Soruda Koronavirüs Sürecinde İş ve Sosyal Güvenlik Hukuku, 2. Baskı, Seçkin Yayıncılık, 2021, s. 51, 52.
} 
13/e) Gezici tele çalışma kapsamında işçilerin işini işyeri veya ev gibi sabit bir yerde yapmayacak olmasının işvereni iş sağlığ1 ve güvenliği yükümlülüklerinden kurtarmayacağı konusunda bir şüphe bulunmamalıdır. Bunun dışında işin evde görülmesi esnasında işle bağlantısı olmayan durumlardan dolayı kazanın meydana gelmesi halinde kazaların iş kazası sayılıp sayılmayacağı hususu tartışmalıdır. Ancak gerek 6331 sayılı Kanunda yer alan "İşyerinde veya işin yürütümü nedeniyle meydana gelen kaza"nın (md. 3/1-g) iş kazasını tanımlaması gerekse 5510 sayılı Kanunun 13. maddesinde yer alan iş kazası tanımında "İşveren tarafından yürütülmekte olan iş nedeniyle..." hükmünden ötürü meydana gelen her kaza iş kazası sayılmamalı, kaza ile görülmekte olan iş arasında illiyet bağı aranmalıdır. Bu açıdan işverenin sorumluluğu görülen işle ilgili meydana gelen kazalarla sınırlı olmalıdır. ${ }^{92}$ Kaza ile zarar arasında aranan illiyet bağı her somut olayın özelliğine göre saptanmalidir. ${ }^{93}$

İşverenin iş sağlığı ve güvenliğini sağlama yükümlülüğü yalnızca işçileri fiziksel risklere karşı korumakla sınırlı değildir. İşverenin bu açıdan psiko-sosyal risklere karşı önlem almak ve işçileri bu açıdan doğabilecek tehlikelere karşı koruma yükümlülüğü de bulunmaktadır. Tele çalışmaya ilişkin AB Çerçeve Anlaşmasında "İşin Düzenlenmesi" başlıklı madde de işverenin işçinin izole olmasını engellemek üzere alması gereken önlemlerden bahsedilmiştir. Düzenlemede "İşveren, düzenli olarak iş arkadaşlarıyla bir araya gelme ve işletmeyle ilgili bilgilere erişme imkânı oluşturmak gibi tele çalışan işçinin, işyerinde çalışan diğer işçilerden izole olmasını engellemeye yönelik tedbirlerin alınmasını sağlar." (md. 9) Tele çalışma türünde dönüşümlü tele çalışma dışında işçiler işyerinden ve iş arkadaşlarından uzaklaşarak yalnızlaşmakta ve bununla beraber psikolojik bir riske maruz kalmaktadır. İşçilerin üzerindeki psikolojik yükü azaltmak amacıyla iş arkadaşlarıyla bir araya gelmelerinin sağlanması, işletmeyle ilgili bilgi almalarının sağlanması gibi çözüm önerileri sunulmuştur. ${ }^{94}$ Ekranlı Araçlarla Çalışmaya İlişkin Yönetmelikte bu tür bir riskten ve işverenin alması gereken önlemden bahsedilmemiştir. Ancak Türk Borçlar Kanunu kapsamında işverenin çalışanları gözetme borcu içerisinde önlem alma yükümlülüğüne psikososyal risklerde eklenmiştir. Bu nedenle İş Kanununda yer alan uzaktan

\footnotetext{
92 DULAY YANGIN (Tele Çalışma), s. 236, 237.

93 SÜMER (İş Sağlığ 1 ve Güvenliği). s. 92.

94 DULAY YANGIN (Tele Çalışma), s. 239, 240.
} 
çalışmaya ilişkin düzenlemede psikososyal risklerden bahsedilmemiş olması işverenin sorumluluğunu ortadan kaldırmayacaktır. Psikososyal riskler ise yalnızca psikolojik taciz ve cinsel taciz ile sınırlı değildir. Yargıtay tarafından verilen bir kararda da "İş ilişkisinde işverenin işçisinin çalışması nedeniyle karşılaşabileceği risk ve tehlikelerden, onun çıkarlarına zarar verecek davranışlardan kaçınması ve bu konuda önlem alması gereklidir"95 denilerek işverenin sorumluluğunun yalnızca psikolojik taciz ve cinsel taciz ile sınırlı olmadığı ifade edilmiştir.

\section{b. Türk Borçlar Kanunu Kapsamında Uzaktan Çalışan İşçilerin İş Sağlığı ve Güvenliğini Sağlama Yükümlülüğü}

Evde hizmet sözleşmeleri kapsamında işverenin işçiyi koruma borcu, çalışan kimselere karşı yerine getirmesi gereken en önemli borçlardandır. Koruma borcu kapsamında işverenin çalıştırdığı işçisini korumak, işçinin çıkarları doğrultusunda gördüğü veya görebileceği muhtemel zararlara karşı gerekli önemleri almak, işçinin haklı çıkarlarına zarar verebilecek davranışlardan kaçınmak gibi çeşitli yükümlülükler barındırır. İşverenin işçiyi koruma borcu, işçinin sadakat borcuna karşı gelen bir yükümlülüktür. İşçinin korunması özünde işçinin kişiliğinin korunmasını barındırır. ${ }^{96}$

İşverenin işçiyi gözetme borcu oldukça geniş kapsamlı bir borçtur. $\mathrm{Bu}$ nedenle işçiyi gözetme borcunun kapsamına nelerin girdiğini önceden sınırlı bir şekilde belirlemek mümkün değildir. Evde hizmet sözleşmeleri kapsamında da işverenin bu açıdan yükümlülükleri tek tek sayılarak belirlenemeyecektir. Bu nedenle bu borcun kapsamı işin niteliği ve Medeni Kanunun ${ }^{97}$ 2. maddesinde yer alan dürüstlük kuralına göre belirlenmelidir. ${ }^{98}$

TBK md. 417 “İş̧̧inin Kişiliğinin Korunması" başlıklı maddede işverenin koruma ve gözetme borcunu düzenlemiştir. Bu başlık kapsamında işçinin kişiliğinin korunmasına ilişkin genel ilkeler, ev düzeni içinde çalışma durumuna ilişkin kurallar ve kişisel verilerin kullanılması konusunda işçinin korunmasına yönelik kurallar düzenlenmiştir. Belirtmek gerekir ki 418. maddede bahsedilen ev düzeni içinde çalışma

\footnotetext{
95 Yarg. 9. HD. 08.03.2016, E: 2014/31063, K: 2016/5132., ÖZDEMIR, s. 36, 37.

96 GÜNAY, s. 372, 373.

$97 \quad$ RG. 8.12.2001, 24607.

$98 \quad$ YAVUZ, s. 518, 519.
} 
hali evde hizmet sözleşmelerini değil ev hizmetlerini kapsamaktadır. Bu nedenle bu çalışma kapsamında bu maddeye değinilmeyecektir.

Evde hizmet sözleşmelerinin düzenlendiği 461. madde ve devamındaki hükümlerde işverenin iş sağlığı ve güvenliğine ilişkin yükümlülüğünü içeren herhangi bir düzenlemeye yer verilmemiştir. 464. maddenin 2. fikrasında yer alan "İşçi işi görürken, kendisine teslim edilen malzemenin veya iş araçlarının bozuk olduğunu belirlerse, durumu hemen işverene bildirir ve işe devam etmeden önce, onun talimatını bekler" hükmü ise işçinin borçları altında düzenlenmiştir ve hükümde işverene ilişkin iş sağlığ1 ve güvenliği yönünden öngörülmüş bir yükümlülük bulunmamaktadır. Bu nedenle evde hizmet sözleşmeleri kapsamında işverenin iş sağlığ1 ve güvenliğini sağlama yükümlülüğü çerçevesinde Kanunun 417. maddesinde yer alan düzenlemeler göz önünde bulundurulacaktır.

417. madde işçinin manevi ve maddi kişisel varlıklarına ilişkin kişiliğin korunmasına dair hükümler içermektedir. Düzenlemenin son fıkrası ise öğretide gerekli olmadığı belirtilerek eleştirilmiştir. İşçilerin kişiliğinin korunmasına dair getirilen bu düzenleme zaten genel hizmet sözleşmeleri ile ilgili olduğundan yani sözleşmeden doğan bir yükümlülük olduğundan ilgili fıkraya isabetli bir şekilde gerek olmadığı savunulmuştur. ${ }^{99}$

İşverenin işçiyi koruma borcu yalnızca işçinin yaşamını, bedensel bütünlügü ve sağlığını korumakla sınırlı olarak algılanmamalıdır. Bu açıdan işveren kendisinden hemen hemen her zaman ekonomik açıdan daha güçsüz konumda olan işçiye bilgi vermeli ve yol göstermeli, işçinin çıkarlarının zedelenmesi için uygun çabayı göstermelidir. Evleviyet ilkesi gereği işveren korumakla yükümlü olduğu maddi ve manevi kişilik değerlerine hukuka aykırı müdahaleden kendisi de kaçınmalıdır. ${ }^{100}$

İşveren işçinin kişilik değerlerine saygı göstermekle yükümlüdür. Kişilik değerleri sınırlı şekilde sayılamaz. Hayatın olağan akışında kişilik değerleri değişmekte ve çeşitlenmekte bununla beraber bu değerlere yönelen saldırı şekilleri de başkalaşmaktadır. Mutlak bir hak olan kişilik hakkı, ihlal etmesi söz konusu olan herkese karşı savunulabilir. İşçinin yaşamı, bedensel bütünlügü ve sağlığı da hiç şüphesiz işverenin koru-

$99 \quad$ KILIÇOĞLU, s. 421.

100 SEVIMLİ K. Ahmet, “Türk Borçlar Kanunu m.417 ve İş Sağlığı ve Güvenliği Kanunu Işığında Genel Olarak İşçinin Kişiliğinin Korunması”, Çalışma ve Toplum, 2013 (1), s. 110. 
makla yükümlü olduğu kişilik değerleri arasındadır. ${ }^{101}$ Bu noktada evde hizmet sözleşmeleri bakımından işverenin iş sağlığı ve güvenliği önlemlerini yerine getirmesinde sosyal ilişkiler ve çalışma ortamı ile ilgili olan faktörlerin etkilerini kapsayan tutarlı ve genel bir önleme politikası geliştirmesi gerektiğini düzenleyen 6331 sayılı İSGK'nın md.5/1-f hükmü gözden kaçırılmamalıdır. TBK md. 417/2 işverenin iş sağlı̆̆1 ve güvenliği ile ilgili alması gereken önlemlerin sınırlarını ortaya koymaktadır. Bu açıdan işverenin sorumluluğu hakkaniyet sorumluluğu değildir. İşveren kendisinden beklenen her türlü önlemi almakla yükümlüdür. ${ }^{102}$ Yargitay tarafından verilen kararlarda da aynı sonuca varılmıştır ve “...Yasa, tüzük ve yönetmeliklerde açıkça gösterilmemiş olsa bile işveren işçi sağl1ğını korumaya yönelik her türlü önlemi almakla yükümlüdür" denilerek sorumluluğun mevzuat düzenlemeleri ile sinırlanamayacağ tir. ${ }^{103}$

TBK md. 417/2 de ifade edilen "işyeri" kavramından "iş organizasyonu" anlaşılmasının isabetli olduğu öğretide savunulmuştur. ${ }^{104}$

\section{c. Uzaktan Çalışma Kapsamında İfa Yardımcılarının Sağlık ve}

\section{Güvenliğini Sağlama Yükümlülüğü}

Evde hizmet sözleşmeleri kapsamında işverenin iş sağllğ̣ ve güvenliği yükümlülüğü bakımından ele alınması gereken önemli durumlardan birisi de iş görme edimini işçinin "bizzat veya aile bireyleriyle birlik$t e^{\prime \prime}$ görmesi halinde aile bireylerinin iş sağlı̆̆ı ve güvenliği açısından işverenin sorumluluğunun ne olacağıdır.

İş Kanunu kapsamında ele alınan uzaktan çalışma hükümlerinde her ne kadar açıkça belirtilmiş olmasa bile iş görme ediminin sorumlusu yalnızca işçidir. Ancak TBK'nın evde hizmet sözleşmesinde açıkça işçinin iş görme edimini aile bireyleriyle birlikte görebileceği düzenlenmiştir. ${ }^{105}$

Evde hizmet sözleşmesi kapsamında aile üyelerinin işi, işçiyle birlikte yerine getirmelerinin hangi sebepten kaynaklandığının herhangi bir önemi bulunmamaktadır. Aile üyelerinin işçi ile beraber iş görmelerinin sebebi aile hukukundan doğan yardım yükümlülüğüne dayanabi-

\footnotetext{
101 SEVIMLİ, s. 124, 125.

102 SEVİMLİ, s. 127-129., GÜNAY, s. 376.

103 Yarg 10. HD. 04.03.2008, E: 2008/2626, K: 2008/7283., GÜNAY, s. 377.

104 GÜNAY, s. 376.

105 ÇELIK/CANIKLIOĞLU/CANBOLAT, s. 232.
} 
leceği gibi hatır ilişkisine veya işveren ile yahut evde hizmet sözleşmesiyle çalışan işçiyle akdedilmiş bir iş sözleşmesine dayanabilir. İşverenle arasında herhangi bir sözleşme ilişkisi bulunmayan aile üyeleri, yardımC1 şahıs konumundadır. ${ }^{106}$ Özetle evde çalışan kişi, adam çalıştıran işverene bağımlı şekilde iş görürken yardımcı şahsın adam çalıştıran kişiye bağımlı olarak çalışması gerekmemektedir bu nedenle yardımcı şahıs kavramı çok daha geniş bir kapsama sahiptir. ${ }^{107}$

Aile bireyleri ile işveren arasında bir sözleşme imzalanmış olup olması işverenin iş sağlığı ve güvenliği sorumluluğunun sinırlarının belirlenmesi açısından önemli olacaktır.

Esasen evde çalışma için yasal düzenlemeler getiren ülkelerde, yasal koruma genel olarak yalnızca evde çalışanın kendisi için öngörülmüştür. Dolayısıyla getirilen düzenlemeler, aile üyeleri ve diğer yardımcılar için geçerli değildir. Bu açıdan evde çalışan kimse ile ifaya yardımcı kişi arasında bir çalışma ilişkisinin doğup doğmadığının da irdelenmesi gerekir. Gerçekten, birçok durumda, yardımcılar ailenin üyesidir. Bu durum gerek yardımcıların alacakları ücret ve gerekse sosyal güvenlikleri açısından bir sorun olarak ortaya çıkmaktadır. Bu duruma ilişkin olarak Fransız İş Kodu, yardımcı kullanan evde çalışanın, işçiler için geçerli tüm mevzuatın yardımcılara da uygulanmasından sorumlu olacağı hükmünü getirmiştir yani Fransız Hukukunda, evde çalışanlar işçi konumunda olmalarına karşılık, yardımcı karşısında işveren sorumluluğu taşımaktadırlar. ${ }^{108}$ Ancak Türk Hukukunda evde çalışan kimselere yardımcı olan kişilerin sorumluluğuna ilişkin özel bir düzenleme bulunmamaktadır. Dolayısıyla ifa yardımcılarının hukukî durumunun belirlenmesinde gerek evde çalışan ile aralarındaki ilişkinin gerekse evde çalıştıran işveren ile aralarındaki ilişkinin niteliğine bakmak gerekecektir.

Eğer evde çalışan kimseye yardımcı olan kişiler ile evde çalışan kişi arasında bir iş ilişkisi varsa bu durumda yardımcı kişilerin işvereni konumunda evde çalışan kişi olacağından TBK kapsamında öngörülmüş işçiyi gözetme borcundan ve dolayısıyla işçilerin sağlık ve güvenliğinden evde çalışan kişi işveren sıfatıyla sorumlu olacaktır. Ancak evde

106 GÜLVER, s. 108.

107 ANTALYA Gökhan. Borçlar Hukuku Genel Hükümler Cilt V/1,2. Güncellenmiş 2. Baskı, Seçkin Yayınevi. 2019, s. 333.

108 KANDEMIR Murat, “Evde Çalışma ve 6098 Sayılı Türk Borçlar Kanunu'nun Evde Hizmet Sözleşmesine İlişkin Hükümleri”, İÜHFM., Cilt: LXXII, Sayı: 2, 2014, s. 148. 
çalışan kişiye yardımcı olan aile üyeleri ile evde çalışan kimse arasında böyle bir iş ilişkisi yoksa evde çalıştıran işverenin sorumluluğunun hukukî dayanağının belirlenmesi gerekir. Belirtilmelidir ki ifa yardımcıları ile işveren arasında iş sözleşmesi kurulmamışsa işveren gerek 6331 sayılı Kanunda gerekse TBK md. 417 kapsamında öngörülen yükümlülüklerden sorumlu tutulmayacaktır. Ancak bu hallerde de ifa yardımcilarının sağlık ve güvenliklerine ilişkin olumsuz bir durumun olması halinde işverenin tamamen sorumluluktan kurtulacağ 1 gibi bir yoruma gidilmemelidir. İşveren genel hükümler uyarınca zarar gören kişilerin zararlarını karşılamakla yükümlüdür.

İfa yardımcılarının başvurabileceği hukukî koruma imkânlarının düzenlendiği hüküm olarak akla TBK md. 66 gelebilir. Ancak adam çalıştıranın sorumluluğunun gündeme gelebilmesi için çalışanın kendisine verilen işin görülmesi esnasında zararın doğması, çalışan kişinin adam çalıştıranla arasında çalıştırma ilişkisinin bulunması gerekir. Çalışma ilişkisi adam çalıştıranın amaçlarına yönelmiş olmalıdır. Çalıştırma ilişkisinde taraflar arasında bağımlılık ilişkisi olmalıdır. Zararın işin görülmesi esnasında ortaya çıkması ve çalışan kimsenin fiili ile ortaya çıan zarar arasında nedensellik bağının bulunması gerekir. ${ }^{109}$ Fakat burada bahsedilen husus adam çalıştıran kişinin iş ilişkisi içerisinde olmayan üçüncü bir kişiye verdiği zarar değildir. Örneğin evde tekstil işlerinin yapıldığı hizmet sözleşmesinde işveren ile aralarında sözleşmenin yapıldığı kişiye yardım eden aile üyelerinden birinin zarar görmesi ancak gördüğü zararın kendi fiili neticesinde gerçekleşmesi ihtimalinde işverenin sorumluluğunun dayanağının ne olacağıdır.

Özel hukuk ilişkilerinde borcun kaynakları ile anlatılmak istenen şey bir tarafı alacaklı diğer tarafı ise borçlu konumuna getiren ve borç ilişkisi olarak ifade edilen durumun hangi hallerde ortaya çıktığıdır. Türk Borçlar Kanununda borcun kaynağı olarak üç husus düzenlenmiştir. Ancak söz konusu kaynakların her birinden doğacak borç ilişkileri sınırlı olarak yorumlanmamalıdır. Hukuksal işlemlerden doğan borçlar, haksız fiilden doğan borçlar ve sebepsiz zenginleşmeden doğan borçlar olarak üç ana ayrımda ele alınan borç kaynakları açısından yapılacak inceleme işverenin sorumluluğunun hukukî dayanağının belirlenmesine

109 ANTALYA, s. 340-347., EREN Fikret, Borçlar Hukuku Genel Hükümler, 25. Baskı, Yetkin Yayınevi, 2020, s. 696 vd., KILIÇOĞLU Ahmet M., Borçlar Hukuku Genel Hükümler (Genel Hükümler), Gözden Geçirilmiş 24. Baskı, Turhan Kitabevi, 2020, s. $423 \mathrm{vd}$. 
yardımcı olacaktır. ${ }^{110} \mathrm{Bu}$ açıdan ifa yardımcısı ile işveren arasında hukukî işleme dayalı bir ilişki olmadığı durumlarda işverenin sorumluluğunun dayanağının TBK md. 49 haksız fiil sorumluluğu olduğu söylenebilecektir. Ancak ifa yardımcısının kendi fiili ile ortaya çıkan zarardan işverenin sorumlu tutulabilmesi için haksız fiilin unsurlarının bir arada bulunması gerekir. Aksi halde işverenin sorumluluğundan bahsedilemeyecektir.

Haksız fiilin unsurları; fiil, zarar, uygun illiyet bağı ve kusurdur. İş sağlığı ve güvenliği kurallarının usulüne uygun olarak alınmaması neticesinde kişinin bedensel bütünlügünün ihlal edilmesi ile beraber maddi bir zarar meydana gelmişse veya kaza ölüm ile neticelenmişse işverenin kusuru varsa haksız fiil hükümleri çerçevesinde sorumlu tutulacaktır. Vücut bütünlüğünün ihlal edilmesi ile beraber zararlı bir sonuç doğmamışsa şahsa verilen zarardan bahsedilemeyecektir. ${ }^{111}$

TBK md. 49 kapsamında işverenin sorumlu tutulabilmesi için aranan şartlardan birisi kusurdur. Haksız fiil sorumluluğunun doğmasında kusur adeta kurucu unsurdur. Her ne kadar madde kapsamında kusurun tanımı yapılmamışsa da öğretide hukuk düzeni tarafından hoş görülmeyen, kınanan davranış şeklinde tanımlanmıştır. Kusur, işverenin sorumluluğunun belirlenmesinde başka bir ifade ile tazminat miktarının belirlenmesinde önemli rol oynar. Bu kapsamda işverenin işin görülmesi esnasında sağlık ve güvenliğin sağlanmasına yönelik alması gereken tüm önlemleri almasına rağmen zarar meydana gelmişse artık bu durumda işveren sorumlu tutulamayacaktır. Kusurun kast ya da ihmal türünün haksız fiil sorumluluğu açısından bir önemi bulunmamaktadır. Ancak kusurun derecesi sorumluluğun kapsamı açısından önemlidir. ${ }^{112}$

\section{d. Uzaktan Çalışma Esnasında 3. Kişilerin Sağlık ve Güvenliğini}

\section{Tehdit Eden Durumlar Kapsamında İşverenin Sorumluluğu}

İşverenin iş sağlığı ve güvenliğini sağlama borcu esasında iş sözleşmesi içerisinde işçinin sadakat borcuna karşılık işçiyi koruma ve gözetme borcu içerisinde yer alan bir borçtur. Dolayısıyla işverenin iş sağlığ1 ve güvenliği önlemleri alma ve işçinin sağlığını ve bedensel bütünlüğünü koruma yükümlülüğü iş ilişkisi içerisinde değerlendirilecektir. Ancak işin görülmesi esnasında işverenin alması gereken sağlık ve gü-

\footnotetext{
110 KILIÇOĞLU (Genel Hükümler), s. 56-58.

111 EREN, s. 597.

112 KILIÇOĞLU (Genel Hükümler), s. 407, 408.
} 
venlik önlemlerini yeterince almaması halinde ya da alınan önlemlere çalışan kişiler tarafından uyulmaması durumunda çalışan kişiler dışında üçüncü kişiler de zarar görebilirler. Esasen çalışmanın konusu uzaktan çalışma kapsamında işverenin iş sağlığ 1 ve güvenliğini sağlama borcu olsa da üçüncü kişilerin sağlık ve güvenliğini tehdit eden bir durum olması halinde işverenin hangi hükümler çerçevesinde sorumlu tutulabileceğine kısaca değinilecektir.

TBK'nın özen sorumluluğu kenar başlığında düzenlenen üç kusursuz sorumluluk halinden ilki md. 66 kapsamında ele alınan adam çalıştıranın sorumluluğudur. Adam çalıştıran, çalışanın kendisine verilen işin yapılması sırasında başkalarına verdiği zararı gidermekle yükümlüdür. Uzaktan çalışma kapsamında bu hükmün ele alınması ve irdelenmesi özellikle evde iş gören çalışanların yapmış oldukları işten ötürü diğer ev halkının sağlık ve güvenliğini tehdit eden bir durum olması halinde işverenin bu durumdan ne şekilde sorumlu olacağı açısından önemlidir. Örneğin evde yerine getirilen tele çalışma esnasında kullanılan teknolojik aletlerin patlaması ile beraber çalışan dışında kimselerin zarar görmesi durumunda işveren hangi düzenlemeler çerçevesinde sorumlu tutulacaktır? Bunun gibi evde çalışma esnasında yapılmakta olan iş ile ilgili kullanılan sağlı̆̆a zararlı kimyasal maddelerin evde yaşayan diğer kimseler tarafından bilinçsizce kullanılması halinde zarar görmesiyle beraber işverenin sorumluluğu ne şekilde belirlenecektir?

Özel düzenlemelerle kısıtlayıcı bir hüküm getirilmemişse TBK md. 66 özel hukuk kapsamında çalışan yardımcı kişinin davranışından doğan tüm sorumluluk halleri için uygulanabilecek genel bir norm niteliğindedir. Başka bir ifade ile söz konusu düzenleme aksi öngörülmemişse özel hukuk ilişkilerinde yardımcı kişinin davranışından doğan sorumluluk hallerine de uygulanabilecek genel bir kuraldır. ${ }^{113}$ Düzenleme ile işverene genel nitelikte, objektif bir özen yükümlülüğü getirilmiştir. Adam çalıştıran kişi çalışanlar üzerindeki denetim ve gözetim yükümlülügünü yerine getirmemesi halinde kanun ile düzenlenmiş olan objektif bir sorumluluğu ihlal etmektedir. ${ }^{114}$

TBK md. 66' da yer alan düzenlemenin özel hukuk ilişkilerinde aksi öngörülmedikçe yardımcı kişilerin davranışından doğan sorumluluk hallerine de uygulanabileceğinden ${ }^{115}$ evde hizmet sözleşmeleri kapsa-

\footnotetext{
113 ANTALYA, s. 329.

114 EREN, s. 696, 697.

115 ANTALYA, s. 329.
} 
mında iş görme edimi aile bireyleri ile yerine getiriliyorsa ve aile bireylerinin fiilinden ötürü 3. kişilerde zarar meydana gelmişse işveren TBK md. 66 kapsamında sorumlu tutulabilecektir. Burada akla TBK md. 116'nın uygulanması durumu gelebilir. Söz konusu düzenlemede iş görmekle yükümlü olan borçlunun sorumluluğu düzenlenmiştir. "Yardımcı kişilerin fiillerinden sorumluluk" başlıklı maddede "Borçlu, borcun ifasını veya bir borç ilişkisinden doğan hakkın kullanılmasını, birlikte yaşadığı kişiler ya da yanında çalışanlar gibi yardımcılarına kanuna uygun surette bırakmış olsa bile, onların işi yürüttükleri sırada diğer tarafa verdikleri zararı gidermekle yükümlüdür" denilerek iş ilişkisinin tarafı olan işverenin değil işçinin sorumluluğu düzenlenmiştir.

TBK md. 66 ve TBK md. 116 birbirine benzer nitelikte düzenlemeler olarak görünseler bile esasen birbirinden oldukça farklı ve birbirleriyle karıştırılmaması gereken iki kurumdur. TBK md. 116 kapsamında düzenlenen sorumluluk sözleşme sorumluluğudur ve yardımcı kişi kullanan kişi ile yardımcı kişinin fiilinden zarar gören kişi arasında bir borç ilişkisi bulunmalıdır. Ancak TBK md. 66 gereği adam çalıştıran kişinin uzaktan çalışma kapsamında bu ilişkinin esas işvereninin sorumlu olması için zarar gören ile arasında borç ilişkisinin bulunmasına gerek yoktur. ${ }^{116}$

TBK md. 66'da düzenlenen ve kusursuz sorumluluk türlerinden biri olan adam çalıştıranın sorumluluğu olağan sebep sorumluluğudur. $\mathrm{Bu}$ açıdan sorumlu kişi kendi kusuru olmasa da özen yükümlülüğünün ihlalinden sorumludur. Böyle bir sorumluluk öngörülmeseydi; işveren işlerini gördüreceği kişileri gelişigüzel seçebilir, onları denetlemeyebilir ya da işin görülmesi esnasında onlara gerekli uyarıları yapmayabilirdi. İşbölümü ihtiyacının daha fazla arttığı günümüz koşullarında gerek adam çalıştıranlar gerekse de çalışan kimseler çoğu zaman başkalarının emeğinden yararlanmak zorunda kalmaktadır. İşin görülmesi esnasında istihdam eden kişi asıl yarar sağlayan olmasına rağmen işin görülmesini bıraktığ 1 kişilerin fiillerinden doğan bir zarar söz konusu olduğunda sorumluluktan kaçmamalıdır. Kanun ile getirilen bu sorumluluk her ne kadar işveren için ağır bir sorumluluk olsa da böylelikle adam çalıştıran işi gördüreceği kişileri seçmede, denetleme ve yönlendirmede ve uyarıda daha dikkatli davranmış olacaktır. ${ }^{117}$ Özellikle evde hizmet sözleşmeleri kapsamında ucuz işgücünden yararlanmak amacıyla iş görecek kişi-

\footnotetext{
116 ANTALYA, s. 333.

117 KILIÇOĞLU (Genel Hükümler), s. 423.
} 
lerde özel bir nitelik aramaya gerek duymayan işverenler açısından bu sorumluluk türü sağlık ve güvenliğin sağlanmasına oldukça büyük katkı sağlayacaktır.

TBK md. 66' da yer alan düzenlemede adam çalıştıran kişiye kurtuluş kanıtı getirilmiştir. Buna göre uzaktan çalışmanın işvereni olan kişi sağlık ve güvenlikle ilgili her türlü özen yükümlülügünü yerine getirdiğini ya da özen yükümlülügünü yerine getirseydi dahi zararın gerçekleşeceğini ispatladığı takdirde sorumluluktan kurtulabilecektir.

\section{SONUÇ}

Türk hukukunda uzaktan çalışma, İş Kanununda uzaktan çalışma ve Türk Borçlar Kanununda evde hizmet sözleşmeleri başlığı altında düzenlenmiştir.

Uzaktan çalışma kapsamında işverenin iş sağlığı ve güvenliği yükümlülüklerine İş Kanununun uzaktan çalışmaya ilişkin 14. maddesinde yer verilmiş ve işverenin bilgilendirme, eğitim verme, sağlı gözetimi yapma ve araç-gereç ve kullanılan ekipmanlarla ilgili gözetimi sağlama yükümlülüğü bulunduğu ifade edilmiştir. Uzaktan Çalışmaya ilişkin Yönetmelik kapsamında da işverenin iş sağlı̆̆1 ve güvenliği yükümlülüklerine değinilmişse de Yönetmelik hükmü, Kanunda yer alan ifadeleri tekrarlamaktan öteye gidememiştir.

İşverenin yükümlülükleri İş Kanununun 14. maddesinde sayılan bu yükümlülüklerle sınırlı olarak yorumlanmamalıdır. Kaldı ki söz konusu hükümde bu yükümlülüklere yer verilmeseydi dahi işveren 6331 sayılı ISGK'da yer alan tüm yükümlülüklerden sorumlu tutulacaktı. Yaşam hakkını korumayı ve işçiler açısından güvenli bir çalışma ortamında bulunulmayı hedefleyen iş sağlığı ve güvenliği hükümlerinin Kanunda bir kez daha tekrar edilmiş olması iş sağlığ1 ve güvenliği kültürünün oluşması açısından olumlu olarak görülebilir. Evde hizmet sözleşmelerine ilişkin düzenlemede ise işverenin iş sağlığ ve güvenliği yükümlülüğünden bahsedilmemiştir. Ancak hizmet sözleşmelerine ilişkin genel hükümlerde yer alan işverenin işçiyi koruma ve gözetme borcu çerçevesinde sağlık ve güvenlik önlemlerini almakla yükümlü olduğu konusunda bir tereddüt bulunmamaktadır.

Uzaktan çalışma kapsamında işverenin iş sağlı̆̆ ve güvenliğini sağlama borcu dört başlık altında ele alınmıştır. İlk olarak İş Kanunu kapsamında çalışan işçilerin sağlık ve güvenliğini sağlama yükümlülüğünün açıklandığ çalışmada işverenin yükümlülügüüün hukukî dayanağını İş Kanununun 14. maddesinde yer alan hüküm ve 6331 sayılı 
İSGK kapsamında yer alan yükümlülükler oluşturmaktadır. İşverenin yükümlülüğü bu açıdan İş Kanunu ve Uzaktan Çalışma Yönetmeliğinde sayılanlarla sinırlı olarak yorumlanmamalıdır.

Türk Borçlar Kanunu kapsamında uzaktan çalışan işçilerin iş sağlığ1 ve güvenliğini sağlama konusunda TBK'nın 417. maddesi uygulama alanı bulacaktır. Bu açıdan işverenin yükümlülüğü yalnızca işçilerin sağlık ve güvenliğini sağlamakla sınırlı değildir. İşveren işçiye bilgi vermeli, yol göstermeli ve işçinin çıkarlarını zedeleyecek her türlü muameleyi önleyebilmeli ve kendisi de bu tür davranışlardan kaçınmalıdır.

Evde hizmet sözleşmeleri TBK'da düzenlenen hükümler gereği işçi tarafından bizzat veya aile üyeleri ile birlikte ifa edilebilecektir. Bu durumda aile üyelerinin iş sağlığı ve güvenliğini sağlama yükümlülüğü konusunda işverenin sorumlu tutulup tutulmayacağı sorusu akla gelebilir. Aile üyeleri hukuken ifa yardımcısı niteliğindedir. İfa yardımcıları ile işveren arasında sözleşme olabileceği gibi sözleşme olmaksızın da aile bireyleri işin görülmesine yardımcı olabilirler. Sözleşmenin olması ihtimalinde işverenin sorumluluğu TBK kapsamında açıklanan durum ile aynıdır. Ancak işveren ile aile bireyleri arasında sözleşmesel bir ilişki bulunmaması halinde işveren aile bireylerinin sağlık ve güvenliğine aykırı bir durum söz konusu olduğunda TBK md. 49 çerçevesinde sorumlu tutulabilecektir. Haksız fiil sorumluluğunun kurucu unsurlarından birinin kusur olduğu göz önüne alındığında da aile bireylerinin zararından işveren ancak kusuru oranında sorumlu tutulabilecektir.

İşverenin yükümlülükleri bakımından bir diğer ihtimal ise çalışanların iş görme edimlerini yerine getirmeleri esnasında üçüncü kişilere verdikleri zarardan işverenin sorumluluğudur. Bu açıdan üçüncü kişiler evde yaşayan diğer bireyler olabileceği gibi bu kişilerden başkası da olabilir. İşverenin sorumluluğu bakımından TBK md. 66'nın uygulanması gündeme gelecektir. Söz konusu düzenleme özen sorumluluğunun ihlali hallerinden birisidir ve kusursuz sorumluluk halidir. İşvereni çalıştıracağ 1 kimseleri seçerken daha özenli davranmaya ve işçilerin denetimini yaparak sağlık ve güvenliği sağlamaya yönlendirecek olan bu düzenleme kapsamında işverenin sorumlu tutulabilmesi için kusur aranmayacaktır. TBK md. 66 genel bir kural niteliğinde olması sebebiyle ifa yardımcılarının fiilleri için de uygulama alanı bulabilecektir. Ancak söz konusu düzenlemede işverene kurtuluş kanıtı getirilmiştir. 


\section{KAYNAKLAR}

ALP, Mustafa, Tele Çalışma (Uzaktan Çalışma), Prof. Dr. Sarper Süzek'e Armağan, 2011, 795-851.

ANTALYA Gökhan, Borçlar Hukuku Genel Hükümler Cilt V/1,2, Güncellenmiş 2. Baskı, Seçkin Yayınevi, 2019, s. 333.

BAŞÖZ Lütfi, ÇAKMAKCI Ramazan, Türk Borçlar Kanunu, Legal Yayınevi, 2013.

BAŞTERZI Süleyman, Avukatla Bağıtlanan Sözleşmenin Hukukî Niteliği, İş Sözleşmesinin Vekâlet ve Diğer İş Görme Sözleşmelerinden Ayrılması, Sicil, Sayı: 17, 2010, 175-199.

BAYRAM Fuat, Türk İş Hukukunda İşçinin Kişilik Hakkını Koruma Borcu, Marmara Üniversitesi Sosyal Bilimler Enstitüsü Yayımlanmamış Doktora Tezi, 2011.

BAYSAL Ulaş, Çalışanların İş Sağlığı ve Güvenliği Yükümlülükleri, Beta Yayınevi, 2019.

CANIKLIIOĞLU Nurşen, 6331 Sayılı İş Sağlığı ve Güvenliği Kanununda Öngörülen İşveren Yükümlülükleri, Çalışma Mevzuatı Seminer Notları, Toprak İşveren Yayınları, 2013.

CIVAN Orhan Ersun, İş Hukukunda Uzaktan Çalışma (Evde Çalışma/Tele Çalışma), İş Hukuku ve Sosyal Güvenlik Hukuku Dergisi, Cilt: 7, Sayı: 26, 2010, 525-575.

ÇELIKK Nuri/CANIKLİOĞLU Nurşen/CANBOLAT Talat, İş Hukuku, Yenilenmiş 33. Bası, Beta, 2020.

DULAY YANGIN Dilek, 6715 Sayılı Yasanın Uzaktan Çalışmaya İlişkin Hükümleri ve Değerlendirilmesi, Sicil, Sayı: 36, 2016, 148-173.

DULAY YANGIN Dilek, Bilgi ve İletişim Teknolojilerinde Yaşanan Gelişimin İş Hukuku Üzerindeki Etkileri: Tele Çalışmaya İlişkin Tespit ve Öneriler, (Tele Çalışma) İş Hukukunda Genç Yaklaşımlar III. Editör: Tankut CENTEL, 2018. 221-261.

DULAY YANGIN Dilek, Endüstri 4.0., Dijitalleşme ve İş Hukukunun Geleceği Dijital Platformların Ortaya Çıkardığı Hukukî İlişkiler Çerçevesinde Değerlendirilmesi, (Dijitalleşme) İstanbul Hukuk Mecmuası, 78 (3), 2020, 1209-1237. 
ERDENK Erdem, İş Hukukunda İsimsiz (Karma ve Kendine Özgü) Sözleşmeler, Legal Yayınevi, 2008.

EREN Fikret, Borçlar Hukuku Genel Hükümler, 25. Baskı, Yetkin Yayınevi, 2020.

EYRENCİ Öner, Çalışma Hayatında Güncel Gelişmeler ve Çağdaş Bir İş Yasası, Sosyal Siyaset Konferansları Dergisi, Sayı: 46, 2002, 157164.

EYRENCİ Öner, Tele Çalışma ve İş Hukuku, İHD Cilt:1, Sayı: 2, 1991.

GÜLVER Ender, Türk Borçlar Kanununun Evde Hizmet Sözleşmesine İlişkin Hükümleri Üzerine, İÜHFM, Cilt: LXXII, Sayı: 2, 2014, 103-122.

GÜMRÜKÇÜOĞLU BOZKURT Yeliz, “Covid-19 Pandemi Döneminde Home-Office Uygulamasına İlişkin Türk ve Alman Hukuku'nda Mukayeseli Bir Değerlendirme." Koronavirüs Döneminde Güncel Hukuki Meseleler Sempozyumu, İstanbul: İbn Haldun Üniversitesi Yayınları, 29-30 Mayıs 2020, 145-207.

GÜNAY Arkın, Türk Hukukunda ve Karşılaştırmalı Hukukta Evden Çalışma, Legal Yayınevi, 2018.

İNCİROĞLU Lütfi, Çalışma Hayatında Esnek Çalışma Uygulamaları, Güncellenmiş 2. Baskı, Legal Yayınevi, 2020.

KANDEMIR Murat, Evde Çalışma ve 6098 Sayılı Türk Borçlar Kanunu'nun Evde Hizmet Sözleşmesine İlişkin Hükümleri, İÜHFM, Cilt: LXXII, Sayı: 2, 2014, 143-166.

KANDEMİR Murat, İş Hukuku ve Sosyal Güvenlik Hukuku Açısından Tele Çalışma, Legal Yayınevi, 2011.

KILIÇOĞLU Ahmet M., Borçlar Hukuku Genel Hükümler, (Genel Hükümler) Gözden Geçirilmiş 24. Baskı, Turhan Kitabevi, 2020.

KILIÇOĞLU Ahmet. M. Borçlar Hukuku Özel Hükümler, Gözden Geçirilmiş Güncelleştirilmiş 2. Bası, Turhan Kitabevi, 2020.

KURT Resul, 250 Soruda Koronavirüs Sürecinde İş ve Sosyal Güvenlik Hukuku, 2. Baskı, Seçkin Yayıncılık, 2021.

OKUR, Zeki, Yeni Teknoloji ve İş Hukuku. Çimento İşveren Dergisi. Cilt: 20, Say1: 3, 2006, 3-19. 
ÖZDEMİR Erdem, İş Sağlığı ve Güvenliği Hukuku Dersleri, Vedat Kitapçlık, 2020.

SEVİMLİ K. Ahmet, Türk Borçlar Kanunu m.417 ve İş Sağlı̆̆1 ve Güvenliği Kanunu Işığında Genel Olarak İşçinin Kişiliğinin Korunması, Çalışma ve Toplum, 2013 (1), 36, 107-148.

SÜMER Halûk Hadî, İş Hukuku Uygulamaları, 7. Baskı, Seçkin Yayınc1lik, 2019.

SÜMER Halûk Hâdi, İş Sağlı̆̆1 ve Güvenliği Hukuku (İş Sağlığ1 ve Güvenliği), Güncellenmiş 4. Baskı, Seçkin Yayıncılık, 2020.

SÜMER Halûk Hadî, İş Sözleşmesinin Bağımlılık Unsuru, (Bağımlılık Unsuru) Sicil, Sayı 19, 2010, 63-74.

SÜZEK Sarper, İş Hukuku, 20. Baskı, Beta Yayınevi, 2020.

ŞAHINN Barış, Bireysel İş Hukuku Açısından Bilgi İşçileri, Ankara Üniversitesi Sosyal Bilimler Enstitüsü: Yayımlanmamış Doktora Tezi, 2016.

ŞEN, Elif, Evde Hizmet Sözleşmesi, Uyuşmazlık Mahkemesi Dergisi. Say1: 10, 2017. 475-505.

TUNCAY, A. Can, Pandemi Gölgesinde Evden Çalışma, İSGHD, Cilt: 18, Say1: 69, 2021, 23-53.

UGAN ÇATALKAYA Deniz, İş Hukukunda Ölçülülük İlkesi, Beta Yayınevi, 2019.

UŞAN Fatih, Parça Başına Çalışmanın Hukukî Niteliği ve Parça Başına Çalışan İşçinin Sorumluluğu, Ankara Hacı Bayram Veli Üniversitesi Hukuk Fakültesi Dergisi, Cilt:4, Sayı: 2, 2000.

ÜÇIŞIK Hasan Fehim, İş Sağlı̆̆ı ve Güvenliği Hukuku, Ötüken Yayınevi, 2021.

YAVUZ Cevdet, Borçlar Hukuku Özel Hükümler, Güncellenmiş ve Yenilenmiş 17. Baskı, Beta Yayınevi, 2021.

YILDIZ Gaye Burcu, İş Hukukunun Etkinliği ve Amacı Üzerine Yeniden Düşünmek, Çalışma ve Toplum 2018/2 (57), 733-748. 